\title{
Spatio-temporal variability in benthic silica cycling in two macrotidal estuaries: Causes and consequences for local to global studies
}

\author{
Mélanie Raimonet ${ }^{\mathrm{a}, *}$, Olivier Ragueneau ${ }^{\mathrm{a}}$, Françoise Andrieux-Loyer ${ }^{\mathrm{b}}$, Xavier Philippon $^{\mathrm{b}}$, \\ Roger Kerouel $^{\mathrm{b}}$, Manon Le Goff ${ }^{\mathrm{a}}$, Laurent Mémery ${ }^{\mathrm{a}}$ \\ a Laboratoire des Sciences de l'Environnement Marin LEMAR, UMR 6539 CNRS-UBO-IRD-Ifremer, Institut Universitaire Européen de la Mer, Plouzané, France \\ ${ }^{\mathrm{b}}$ DYNECO Pelagos, Ifremer, Plouzané, France
}

\section{A R T I C L E I N F O}

Article history:

Received 29 March 2012

Accepted 27 December 2012

Available online 17 January 2013

\section{Keywords:}

heterogeneity

season

silicate

sediment

land-sea interface

upscaling

\begin{abstract}
A B S T R A C T
The high heterogeneity of silica cycling in coastal margins and the lack of silica data (compared to nitrogen and phosphorus) prevent the estimation of global silica retention in estuaries. In this study, the spatial and temporal variability of porewater silicic acid $\left(\mathrm{Si}(\mathrm{OH})_{4}\right)$ profiles - that integrate benthic transport and reaction processes - was investigated at different spatial (metre, longitudinal and crosssection, intra-estuary) and temporal (tidal, seasonal) scales in two macrotidal estuaries, very close geographically but essentially differing in their shape. Studying the spatial and temporal variability of $\mathrm{Si}(\mathrm{OH})_{4}$ concentrations in porewaters provided evidence for the importance of transport processes, e.g. bio-irrigation, tidal pumping, resuspension and any combination of these processes, in affecting $\mathrm{Si}(\mathrm{OH})_{4}$ concentrations and fluxes and therefore temporary or permanent retention along the land-ocean continuum. We confirm that $\mathrm{aSiO}_{2}$ (amorphous silicate) transported by rivers and estuaries clearly needs to be better characterized as it provides an important source of reactive $\mathrm{aSiO}_{2}$ to sediments. This study allows us to: (1) interrogate spatial and temporal scales, although both are most often in complete interaction; (2) design the most appropriate sampling schemes to be representative of any given system and to extrapolate at the scale of the whole estuary; (3) quantify uncertainty associated to the estimations of $\mathrm{Si}(\mathrm{OH})_{4}$ stocks and fluxes in this type of ecosystem, essential for budget calculations. We showed that two adjacent small macrotidal estuaries, may exhibit different behaviours regarding Si retention. Temporary retention has been observed in the meanders of the Aulne Estuary and not along the more linear Elorn Estuary, demonstrating the importance of the morphology and hydrodynamic components of the estuarine filter. Research is needed in other systems and climatic zones, but our study suggests that the typology should not only account for the different types of land-ocean continuum (fjord, delta, mangrove...), but also incorporate the physical or biological attributes of the estuarine filter.
\end{abstract}

(C) 2013 Elsevier Ltd. All rights reserved.

\section{Introduction}

The silica ( $\mathrm{Si}$ ) cycle - and especially estimating the transient and permanent retention of $\mathrm{Si}$ - has important ecological and biogeochemical implications at small to global scales. At the local scale, higher Si retention leads to Si limitations and decreasing Si:N and Si:P ratios. These environmental modifications are responsible for shifts in phytoplanktonic communities dominated by diatoms to other species e.g. cyanobacteria or toxic dinoflagellates, which have repercussions on higher trophic levels (Officer and Ryther, 1980; Conley et al., 1993; Cloern, 2001; Howarth et al., 2011). Such Si

\footnotetext{
* Corresponding author. Current address: UMR 7619 Sisyphe, Université Pierre et Marie Curie, 4 Place Jussieu, 75252 Paris, France.

E-mail addresses: melanie.raimonet@univ-brest.fr, melanie.raimonet@gmail.com (M. Raimonet).
}

limitations and eutrophic events have however been prevented by benthic recycling and fluxes associated to transient retention in several estuarine and coastal shallow ecosystems (Yamada and D'Elia, 1984; Ragueneau et al., 2002a; Struyf et al., 2006; Laruelle et al., 2009). At the global scale, permanent retention decreases the export of Si to the ocean, while bioavailable Si has an essential role in enhancing the biological carbon pump by increasing particle sedimentation rate, aggregate formation, and protection from organic matter degradation (Smetacek, 1985; Moriceau et al., 2007, 2009). A knowledge of Si cycling along land-sea continuum is particularly essential as coastal margins - including estuaries must strongly contribute to Si sinking (Bernard et al., 2010).

Nevertheless, the heterogeneity of Si cycling is still poorly quantified from local to global scales (Jansen et al., 2010; Ragueneau et al., 2010; Moosdorf et al., 2011; Dürr et al., 2011a), especially in estuaries (Dürr et al., 2011a). The difficulty in 
estimating estuarine heterogeneity is related to the high spatial and temporal environmental variability. Estuaries are generally characterized by the most heterogeneous and changing environmental conditions because of numerous external forces and human activities (Nichols et al., 1986; Dalrymple and Choi, 2007). In order to decrease uncertainties in estuaries, heterogeneity must thus be explored to design associated sampling schemes (Dutilleul, 1993), to validate interpretations of ecosystem functioning (Livingston, 1987; Hunt et al., 1997) and to ensure the quality of long-term records (Wolfe et al., 1987). These quantifications are also necessary to estimate errors during downscaling and upscaling, and prevent significant errors incurred by failing to resolve spatial and temporal variation (Swaney and Giordani, 2007; Swaney et al., 2012).

The variability of Si cycling, including retention, is strongly controlled by transport and reaction processes. Transport processes are either physical, e.g. deposition and erosion of amorphous silica $\left(\mathrm{aSiO}_{2}\right.$ ) (Arndt and Regnier, 2007), or biological, e.g. bioturbation, bioirrigation (Aller, 1980; Berner, 1980), while reaction processes are either chemical, e.g. dissolution and/or reprecipitation of $\mathrm{aSiO}_{2}$ (Berner, 1980; Michalopoulos and Aller, 2004), or biological, e.g. filtration of $\mathrm{aSiO}_{2}$ by benthic filter feeders (Ragueneau et al., 2002a), uptake of dissolved silica $\left(\mathrm{Si}(\mathrm{OH})_{4}\right)$ by benthic diatoms or sponges (Ni Longphuirt et al., 2009), all these processes depending on environmental factors. Even if the riverine flux of $\mathrm{aSiO}_{2}$ to the ocean has generally been neglected compared to the $\mathrm{Si}(\mathrm{OH})_{4}$ flux (Tréguer et al., 1995), it may constitute some 16-40\% of the total Si inputs to estuaries (Conley, 1997; Smis et al., 2010; Tréguer and De La Rocha, 2013) which may, at least partly, settle in sediments. Depending on catchments and seasons, estuarine $\mathrm{aSiO}_{2}$ can be derived from terrestrial ecosystems, e.g. forest, grassland, wetland, soil (Conley, 2002; Blecker et al., 2006; Gérard et al., 2008; Struyf and Conley, 2009), and/or from diatoms growing in rivers (Conley, 1997).

The many heterogeneous environmental parameters and processes occurring in estuaries moreover lead to variations of $\mathrm{Si}$ stocks and fluxes at different spatial and temporal scales. At small scales, processes such as tidal resuspension or biological activity, lead to hourly, daily, seasonal and spatial variations of benthic $\mathrm{Si}(\mathrm{OH})_{4}$ fluxes (Sakamaki et al., 2006; Ni Longphuirt et al., 2009; Leynaert et al., 2011). At larger scales, annual and regional variations of Si fluxes and retention are generated by different intrinsic properties, e.g. lithology, land cover, climate, runoff (Jansen et al., 2010; Moosdorf et al., 2011; Dürr et al., 2011a), and human activities, e.g. eutrophication, dam building, population density, invasive species (Conley et al., 1993; Humborg et al., 1997; Roy et al., 1999; Ragueneau et al., 2002a).

The rapid response of estuarine ecosystems to environmental parameter variations makes the characterization of material fluxes (i.e. $\mathrm{aSiO}_{2}$ and $\mathrm{Si}(\mathrm{OH})_{4}$ ) within the sediment and at the sedimentwater interface very difficult (Matisoff et al., 1975; Arndt and Regnier, 2007). Investigating spatial and temporal variations of porewater $\mathrm{Si}(\mathrm{OH})_{4}$ concentrations allows us, however, to integrate benthic process variations related to changing environmental factors. Porewater profiles of $\mathrm{Si}(\mathrm{OH})_{4}$ - or other dissolved metabolites - are then used to estimate biogeochemical rates and fluxes (Khalil et al., 2007; Lettmann et al., 2012). Measurements of porewater $\mathrm{Si}(\mathrm{OH})_{4}$ profiles and their variability are thus useful to evaluate the variability of benthic processes, but also the representativeness and uncertainty of porewater $\mathrm{Si}(\mathrm{OH})_{4}$ concentrations in estuarine sampling.

The Bay of Brest is an example of a macrotidal system under an oceanic climate, downstream of a silicified catchment impacted by strong anthropogenic nitrogen enrichment (Del Amo et al., 1997a). This shallow coastal embayment is characterized by a coastal biological - silicate pump associated to benthic fluxes (Del Amo et al., 1997b), increased by the presence of benthic filter-feeders which prevent dinoflagellate blooms (Ragueneau et al., 2000; Laruelle et al., 2009). While numerous studies have been performed in the bay, no studies were undertaken on benthic Si cycling in the brackish estuaries. Describing benthic spatio-temporal variability and the main transport and reaction processes involved is then necessary to evaluate the uncertainty associated with benthic processes and fluxes. The two main estuaries flowing into the Bay (e.g. Elorn and Aulne) are very close but characterized by different shapes and hence appropriate to determine the impact of linear and S-shape morphology on benthic Si cycle.

This study investigated spatial and temporal variability of benthic $\mathrm{Si}(\mathrm{OH})_{4}$ concentrations in two estuaries at various scales (tide, cross-section, intra-estuary, season). It describes and compares the variability of porewater $\mathrm{Si}(\mathrm{OH})_{4}$ concentrations in the two estuaries, and emphasizes the main environmental factors, transport and reaction processes explaining this variability. Here we discuss the implications of these results for local, regional and global investigations: Does the small scale variability allow studying seasonal and intra-estuary variations? Is the heterogeneity similar between two macrotidal and temperate estuaries? What is the impact on estimations of model uncertainty?

\section{Material and methods}

\subsection{Study site}

The Elorn and Aulne estuaries are located at the interface between their drainage basins and the semi-enclosed Bay of Brest in Northwestern France (Fig. 1). These two estuaries supply up to 85\% of fresh water inputs to the Bay of Brest. They are characterized by similar catchment lithology, climate and tidal regime, but have a different size, morphology and land use. The lithology of the two catchments is similarly dominated by silica-enriched rocks, mainly granite and schist (Lague et al., 2000). The two catchments are both characterized by intensive agriculture activities. Urbanization is greater in the Elorn catchment. The oceanic climate of the region creates precipitation of $1145 \mathrm{~mm} \mathrm{yr}^{-1}$ (average for the 30-year period 1971-2000; World Weather Organization, http://www. wmo.int). Monthly temperatures for this period ranged from $6.7{ }^{\circ} \mathrm{C}$ in January to $16.8{ }^{\circ} \mathrm{C}$ in August. The Aulne catchment is 8 times larger than the Elorn catchment (1822 versus $280 \mathrm{~km}^{2}$ ). The Aulne River discharge is thus more than four times larger than the Elorn River one in winter. The Aulne and Elorn river discharges decrease from winter (42 and $189 \mathrm{~m}^{3} \mathrm{~s}^{-1}$ in 2009) to summer (1.0 and $1.7 \mathrm{~m}^{3} \mathrm{~s}^{-1}$ in 2009; Banque Hydro, http://www.hydro. eaufrance.fr). As for the catchment area, the length of the Elorn Estuary is smaller $(\sim 15 \mathrm{~km})$ compared to the Aulne Estuary $(\sim 35 \mathrm{~km})$. The morphology of the Elorn Estuary is straight and more directly exposed to marine hydrodynamic influence, while the Aulne estuary is meandering and more protected by the Bay of Brest. The semi-diurnal tidal amplitude of $4 \mathrm{~m}$ (7.5 m during spring tides) in the Bay of Brest results in intense variations of water depth in these two estuaries, and to sediment deposition and erosion (Aulne Estuary; Bassoulet, 1979). All these properties, and principally the catchment lithology and the river flow regime, lead to high $\mathrm{Si}(\mathrm{OH})_{4}$ fluxes to the Bay of Brest. Due to a larger drainage basin area and river flow, the Aulne River $\mathrm{Si}(\mathrm{OH})_{4}$ fluxes are generally higher than the Elorn River ones. The relative $\mathrm{Si}(\mathrm{OH})_{4}$ fluxes to the Bay of Brest range from $40 \%$ (in summer) to $80 \%$ (in winter). ${ }^{1}$

\footnotetext{
${ }^{1}$ Data not shown. $\mathrm{Si}(\mathrm{OH})_{4}$ flux was calculated by multiplying $\mathrm{Si}(\mathrm{OH})_{4}$ concentration with the river flow at the exutory of Elorn and Aulne rivers. Relative $\mathrm{Si}(\mathrm{OH})_{4}$ fluxes to the Aulne Estuary was calculated as the proportion of the Aulne $\mathrm{Si}(\mathrm{OH})_{4}$ flux divided by the sum of Elorn and Aulne $\mathrm{Si}(\mathrm{OH})_{4}$ fluxes.
} 


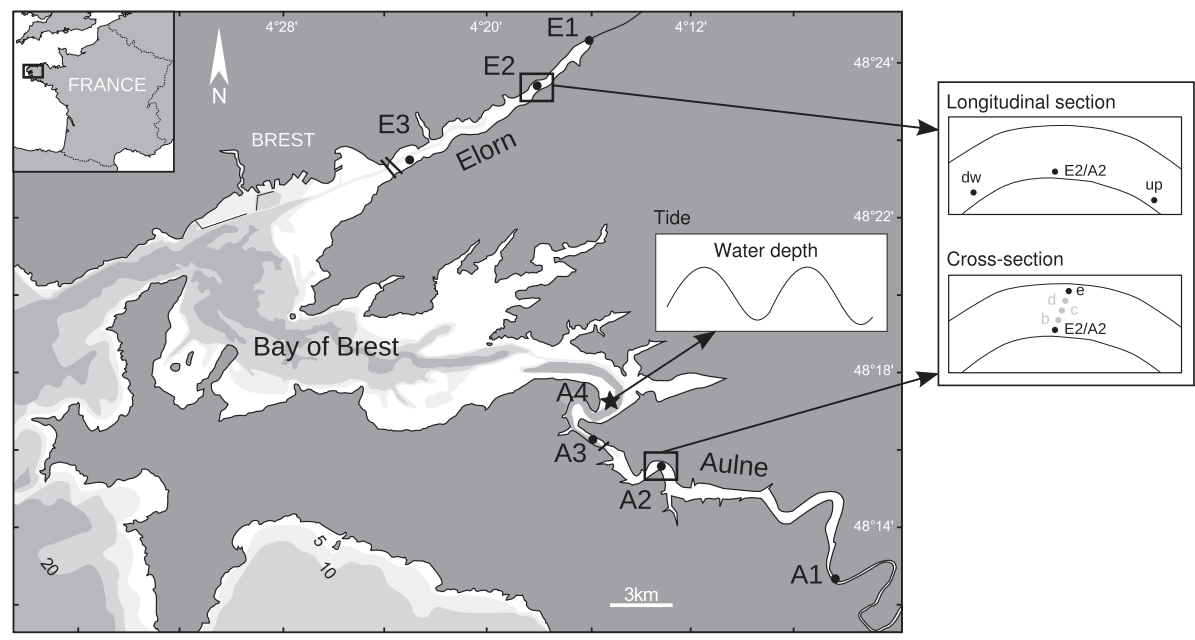

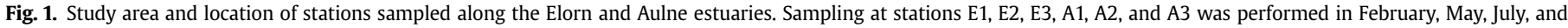

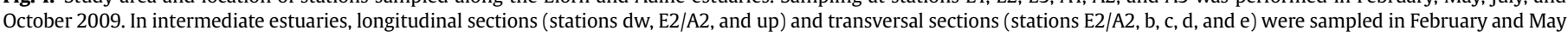
2009, respectively. High-frequency sampling was performed over tidal cycles at station A4 (black star) in July 2009.

\subsection{Sampling design}

Sampling was performed along the Elorn and Aulne estuaries (Fig. 1) in February, May, July, and October 2009. In order to interpret intra-estuary, inter-estuary and seasonal variations, small spatial and temporal variability were investigated first. All the different scales are summarized in Table 1.

\subsubsection{Small scale sampling}

2.2.1.1. Centimetre scale. Vertical porewater profiles were analysed at a resolution of $0.5 \mathrm{~cm}$ in surface to $4 \mathrm{~cm}$ at $20 \mathrm{~cm}$-depth in each sediment core.

2.2.1.2. Metre scale. Variability at the metre scale was investigated through the sampling of three cores at each station (E1, E2, E3, A1, A2, A3 and A4) and season $(n=3)$.

2.2.1.3. Longitudinal transect. In both the Elorn and Aulne estuaries, longitudinal variations were quantified by sampling sediment cores at three stations located at a same tidal level on the left subtidal shores (stations up, E2/A2, dw) in February 2009 (Fig. 1). Left shores are located on the left border along the upper-lower axis of the estuary. Distance between the three stations was $100-1000 \mathrm{~m}$ depending on stations.

2.2.1.4. Cross-section. In both estuaries, sediment cores were sampled in the channel (stations c) in February 2009, and at five stations from the left to the right borders (stations E2/A2, b, c, d and e) in May 2009. Cross-section widths were $\sim 75$ and $\sim 200 \mathrm{~m}$ in intermediate Elorn and Aulne estuaries, respectively.

Table 1

List of the spatial and temporal variations of porewater $\mathrm{Si}(\mathrm{OH})_{4}$ concentrations investigated at small and large scales in this study. The associated unit scale and figure numbers are indicated in the last two columns.

\begin{tabular}{cllll}
\hline & & Unit scale & Name & Figs. \\
\hline Spatial & Small scale & $\mathrm{cm}$ & Vertical distribution & $2,3,4,5,6$ \\
variations & & $\mathrm{m}$ & Triplicate & $5,6,7$ \\
& & $10-100 \mathrm{~m}$ & Longitudinal transect & 2 \\
& & $10-100 \mathrm{~m}$ & Cross-section & 3 \\
& \multirow{2}{*}{ Large scale } & $\mathrm{km}$ & Salinity gradient & 6 \\
& & $\mathrm{~km}$ & Inter-estuary & 6,7 \\
Temporal & Small scale & $\mathrm{h}-\mathrm{d}$ & Tide & 5 \\
variations & Large scale & $\mathrm{d}-\mathrm{yr}$ & Season & 6,7 \\
\hline
\end{tabular}

2.2.1.5. Tide. High-frequency sampling was performed on board the Hésione every $2 \mathrm{~h}$ over $12 \mathrm{~h}$ in July 2009 in the outer Aulne Estuary (station A4; Fig. 1).

2.2.2. Intra-estuary, inter-estuary and seasonal sampling

2.2.2.1. Intra- and inter-estuary sampling. Intra- and inter-estuarine variation was investigated by sampling at three stations located in upper (stations E1 and A1), intermediate (stations E2 and A2) and outer (stations E3 and A3) estuaries (Fig. 1). Sampling was always performed at mid-tide on subtidal sediments located between the channel and the border.

2.2.2.2. Seasonal sampling. Sampling at the three stations located along each estuary was performed in February, May, July, and October 2009.

\subsection{Sediment and water analyses}

Core sampling was achieved using a gravity corer $\left(\right.$ UWITEC $\left.^{\circledR}\right)$ with Plexiglas ${ }^{\circledR}$ cores $(9.5 \mathrm{~cm}$ diameter $\times 60 \mathrm{~cm}$ long). Corer weight was adjusted to allow a penetration of $30 \mathrm{~cm}$ into the sediment. This gravity corer facilitated acquisition of an undisturbed sediment-water interface. Overlying water temperature and salinity were immediately measured with a salinometer after sampling. Sediment cores were immediately sliced every $0.5 \mathrm{~cm}$ in the first $2 \mathrm{~cm}$, every $1 \mathrm{~cm}$ down to $4 \mathrm{~cm}$, every $2 \mathrm{~cm}$ down to $12 \mathrm{~cm}$, and every $4 \mathrm{~cm}$ down to $20 \mathrm{~cm}$. Sediment sections were placed in sealed 50 -ml centrifugation tubes containing Vectaspin 20 filters $(0.45 \mu \mathrm{m}$ pore size, Whatman ${ }^{\circledR}$ ) as described in Andrieux-Loyer et al. (2008). Interstitial waters were extracted by centrifugation at $3500 \mathrm{rpm}$ for $10 \mathrm{~min}$ ( 2 times) at $4{ }^{\circ} \mathrm{C}$. Overlying and porewaters were acidified to $\mathrm{pH}=2$ with $\mathrm{HCl}$. An aliquot was preserved at $4{ }^{\circ} \mathrm{C}$ for analyses of $\mathrm{Si}(\mathrm{OH})_{4}$ concentrations.

An aliquot of non-centrifuged bulk sediment was stored at $4{ }^{\circ} \mathrm{C}$ for less than $15 \mathrm{~d}$ for granulometry measurements. Centrifuged sediments were freeze-dried for $48 \mathrm{~h}$, placed at $60{ }^{\circ} \mathrm{C}$ to ensure complete sediment dryness, and slightly powdered for further analyses of amorphous silica $\left(\mathrm{aSiO}_{2}\right)$ concentrations in the solid fraction and dissolution experiments.

Surface waters were also collected at $1 \mathrm{~m}$ depth along the salinity gradient of the two estuaries. An aliquot of 100-200 ml of surface water was filtered on a polycarbonate filter $(0.6 \mu \mathrm{m}$ pore size) and stored at $4{ }^{\circ} \mathrm{C}$ until $\mathrm{Si}(\mathrm{OH})_{4}$ measurements. The membrane 
was dried for $48 \mathrm{~h}$ at $60{ }^{\circ} \mathrm{C}$ and stored at room temperature until $\mathrm{aSiO}_{2}$ analyses.

\subsection{Laboratory analyses}

Sediment grain size analyses were performed with a laser-based particle size analyser (LS Beckman Coulter). Pelagic $\mathrm{aSiO}_{2}$ concentrations were determined by using the sequential alkaline digestion method of Ragueneau et al. (2005) and benthic $\mathrm{aSiO}_{2}$ contents were quantified by using the method of DeMaster (1981). Both methods allowed correcting amorphous silica concentrations from lithogenic silica interference which is essential in environments rich in aluminosilicates - e.g. estuaries. Even if results can be relatively different depending on the extraction method, comparisons of different methods have been performed by Rebreanu (2009) which showed that the method of DeMaster (1981) was particularly suitable in estuarine sediments in the Scheldt continuum.

For pelagic $\mathrm{aSiO}_{2}$ concentrations, polycarbonate filters were used for two sequential extractions at $\mathrm{pH} 13.3$ for $40 \mathrm{~min}$. $\mathrm{aSiO}_{2}$ concentrations were calculated with the equation defined by Ragueneau et al. (2005):

$\left[\mathrm{aSiO}_{2}\right]_{\mathrm{corr}}=[\mathrm{Si}]_{1}-[\mathrm{Al}]_{1} \times\left([\mathrm{Si}]_{2} /[\mathrm{Al}]_{2}\right)$

$[\mathrm{Si}]_{1}: \mathrm{Si}(\mathrm{OH})_{4}$ concentrations in supernatant after the first digestion

$[\mathrm{Al}]_{1}$ :Aluminium $(\mathrm{Al})$ concentrations in supernatant after the first digestion

$[\mathrm{Si}]_{2}: \mathrm{Si}(\mathrm{OH})_{4}$ concentrations in supernatant after the second digestion

$[\mathrm{Al}]_{2}: \mathrm{Al}$ concentrations in supernatant after the second digestion

Triplicate measurements of aluminium $(\mathrm{Al})$ concentrations were performed using the manual fluorescent method, by adding lumogallion which forms a fluorescent complex with Al. Excitation and emission wave lengths are $492 \mathrm{~nm}$ and $565 \mathrm{~nm}$, respectively.

For the quantification of benthic $\mathrm{aSiO}_{2}$ concentrations, $30 \mathrm{mg}$ of surficial sediments $(0-0.5 \mathrm{~cm})$ was added to $50 \mathrm{ml}$ of $\mathrm{Na}_{2} \mathrm{CO}_{3} 5 \%$ and incubated at $85^{\circ} \mathrm{C}$ for $6 \mathrm{~h}$. At $0.5,1,2,3,4,5,6 \mathrm{~h}$, the vials were centrifuged for $15 \mathrm{~min}$ at $4000 \mathrm{rpm}$. $0.5 \mathrm{ml}$ of supernatant was put in $9.2 \mathrm{ml}$ of ultrapure water to prevent problems with the reagent, and neutralized at $\mathrm{pH} 7$ with $\mathrm{HCl} 10 \%$. The mass percentage of $\mathrm{aSiO}_{2}$ was graphically represented as a function of time. According to the DeMaster (1981) method, the content in $\mathrm{aSiO}_{2}$ was given by the $y$ intercept of the linear part of the plot (after $2 \mathrm{~h}$ ). Note that benthic
$\mathrm{aSiO}_{2}$ concentrations are expressed as \% in this study to refer to $\mu \mathrm{g} \mathrm{gDW}{ }^{-1}$.

$\mathrm{Si}(\mathrm{OH})_{4}$ concentrations were determined with an AutoAnalyzer III (Bran + Luebbe $^{\circledR}$ ) using the method of Tréguer and Le Corre (1975). The precision of the analysis was $0.5 \%$. Note that the overall dataset of $\mathrm{Si}(\mathrm{OH})_{4}$ concentrations is available in the Annexe.

\subsection{Statistical methods}

All statistical analyses described below were performed with $\mathrm{R}$ software (http://cran.r-project.org). Before each test, the normality and homoscedasticity of data sets were assessed with the ShapiroWilk and Bartlett tests, respectively. Parametric ANOVA and nonparametric Kruskal-Wallis tests were performed to examine station and seasonal differences in $10-\mathrm{cm}$ integrated $\mathrm{Si}(\mathrm{OH})_{4}$ concentrations $\left(\int \mathrm{Si}(\mathrm{OH})_{4}\right)$ occurring for longitudinal, cross-section, tidal, and seasonal samplings in the Elorn and Aulne estuaries. Tukey post-hoc tests and multiple comparison tests were performed after ANOVA and Kruskal-Wallis tests, respectively, to identify the significantly different groups. The Wilcoxon test was used to find the significant differences in intra- and inter-tidal measurements of $\int \mathrm{Si}(\mathrm{OH})_{4}$ performed in February and July. For all tests, a probability of 0.05 was used to determine statistical significance.

The minimum (min), maximum (max) and average (avg) of porewater $\mathrm{Si}(\mathrm{OH})_{4}$ concentrations, as well as the standard deviation (SD) and coefficient of variation ( $\mathrm{CV}$, the standard deviation as a percentage of the mean) were summarized for the different scales investigated in Table 2. Clustering (the Ward method) was used to investigate differences between the sum of squared distances integrated over $10 \mathrm{~cm}$ at stations E2 and A2 to compare variations in $\mathrm{Si}(\mathrm{OH})_{4}$ profiles at the metre, pluri-metre (longitudinal and crosssection), and seasonal scales.

\section{Results}

\subsection{Benthic variability at small spatial and temporal scales}

\subsubsection{Longitudinal transect}

In the intermediate Elorn Estuary, porewater $\mathrm{Si}(\mathrm{OH})_{4}$ profiles were similar at all stations sampled at a same tidal level on the left shore (Fig. 2). Porewater $\mathrm{Si}(\mathrm{OH})_{4}$ concentrations increased from 80 to $130 \mu \mathrm{mol} \mathrm{l}^{-1}$ at the surface to $300-330 \mu \mathrm{mol} \mathrm{l}{ }^{-1}$ at $20 \mathrm{~cm}$ depth. In the intermediate Aulne Estuary, a very different profile was monitored at station A2 with subsurface $\mathrm{Si}(\mathrm{OH})_{4}$ concentrations reaching $580 \mu \mathrm{mol} \mathrm{l}^{-1}$ (Fig. 2). With the exception of this distinct profile, porewater $\mathrm{Si}(\mathrm{OH})_{4}$ profiles were similar at all stations sampled on the left shore in the Aulne Estuary. In general,

Table 2

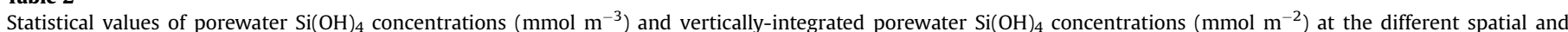

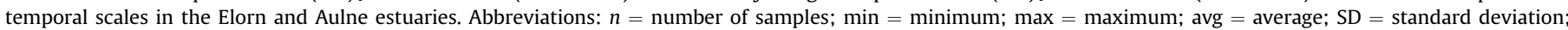
$\mathrm{CV}=$ coefficient of variation (the standard deviation as a percentage of the mean).

\begin{tabular}{|c|c|c|c|c|c|c|c|c|c|}
\hline Estuary & Scale name & Unit & $n$ & Min & Max & Median & Avg & SD & $\mathrm{CV}$ \\
\hline \multirow[t]{7}{*}{ Elorn } & Depth & $\mathrm{mmol} \mathrm{m}^{-3}$ & 144 & 17 & 429 & 192 & 206 & 81 & 40 \\
\hline & Triplicate & $\mathrm{mmol} \mathrm{m}^{-2}$ & $3 \times 12$ & $14-24$ & $16-27$ & $14-26$ & $15-24$ & $0-5$ & $2-25$ \\
\hline & Longitudinal section & & 3 & 23 & 24 & 24 & 23 & 1 & 3 \\
\hline & Cross-section & & 5 & 11 & 17 & 16 & 15 & 2 & 17 \\
\hline & Salinity gradient & & 3 & 18 & 23 & 20 & 20 & 2 & 11 \\
\hline & Tide & & - & - & - & - & - & - & - \\
\hline & Season & & 4 & 19 & 21 & 20 & 20 & 1 & 4 \\
\hline \multirow[t]{7}{*}{ Aulne } & Depth & $\mathrm{mmol} \mathrm{m}^{-3}$ & 144 & 37 & 830 & 279 & 300 & 141 & 47 \\
\hline & Triplicate & $\mathrm{mmol} \mathrm{m}^{-2}$ & $3 \times 12$ & $15-41$ & $19-81$ & $17-51$ & $17-51$ & $0-30$ & $1-59$ \\
\hline & Longitudinal section & & 3 & 13 & 40 & 38 & 30 & 15 & 49 \\
\hline & Cross-section & & 5 & 20 & 51 & 24 & 29 & 12 & 42 \\
\hline & Salinity gradient & & 3 & 27 & 32 & 32 & 30 & 3 & 9 \\
\hline & Tide & & 6 & 19 & 30 & 23 & 24 & 4 & 17 \\
\hline & Season & & 4 & 22 & 38 & 31 & 30 & 8 & 26 \\
\hline
\end{tabular}


A. Elorn Estuary

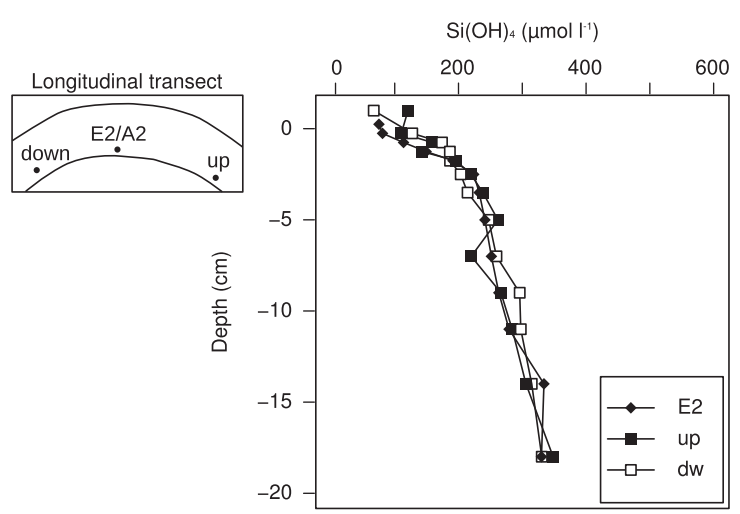

B. Aulne Estuary

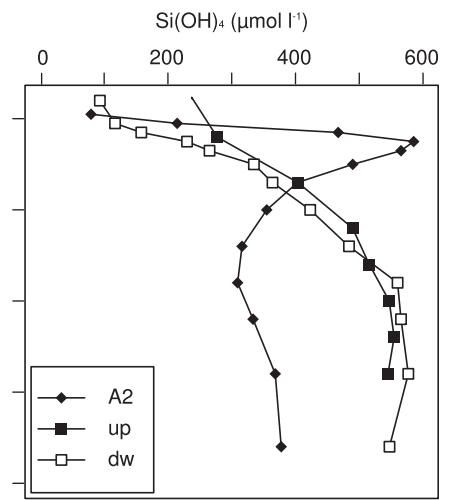

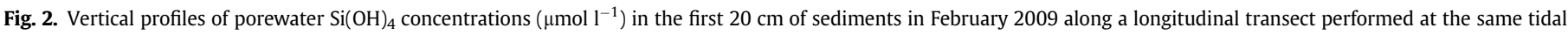
level (stations up, E2/A2, and dw; Fig. 1) in intermediate Elorn and Aulne estuaries.

Table 3

Results of statistical tests for the comparison between the smallest spatial and temporal scales in the Elorn and Aulne estuaries. The scales compared are indicated in two columns by $n^{\circ} 1$ and $n^{\circ} 2$. Abbreviations: $\mathrm{df}=$ degree of freedom; $K^{2}$ and $V=$ statistical value for each statistical test; $p=p$ value.

\begin{tabular}{lllllll}
\hline Estuary & Scale $^{\circ} 1$ & Scale $^{\circ} 2$ & Statistical test & df & $K^{2}$ or $V$ & $p$ \\
\hline Elorn & Triplicate & Longitudinal section & Kruskal-Wallis & 1 & 0.05 & 0.83 \\
& & Cross-section & Kruskal-Wallis & 1 & 0.20 & 0.6547 \\
Aulne & Triplicate & Longitudinal section & Kruskal-Wallis & 1 & 0.05 & 0.83 \\
& & Cross-section & Kruskal-Wallis & 1 & 3.75 & 0.05 \\
& & Tide & Wilcoxon & - & 21 & $\mathbf{0 . 0 3}$ \\
\hline
\end{tabular}

Significant differences are indicated by bold and italic values for $p<0.05$ and $p=0.05$, respectively.

porewater $\mathrm{Si}(\mathrm{OH})_{4}$ concentrations were higher in the Aulne Estuary than in the Elorn Estuary (Table 2, avg) and increased from 110 to $230 \mu \mathrm{mol} \mathrm{l}^{-1}$ at the surface to $380-560 \mu \mathrm{mol} \mathrm{l}^{-1}$ at $20 \mathrm{~cm}$ depth. The $10-\mathrm{cm}$ integrated $\mathrm{Si}(\mathrm{OH})_{4}$ concentrations $\left(\int \mathrm{Si}(\mathrm{OH})_{4}\right)$ was not significantly different along longitudinal transects than between triplicates in both intermediate estuaries (Table 3 ). The coefficient of variation (CV) was however very low in the Elorn Estuary (2-3\%), but high in the Aulne Estuary (20-49\%), regardless of triplicate or longitudinal sampling in intermediate estuaries (Table 2 and Fig. 2).

\subsubsection{Cross-section}

In the intermediate Elorn Estuary, porewater $\mathrm{Si}(\mathrm{OH})_{4}$ profiles were similar across the estuarine section (Fig. 3A). Porewater
$\mathrm{Si}(\mathrm{OH})_{4}$ concentrations regularly increased from 80 to $100 \mu \mathrm{mol} \mathrm{l}^{-1}$ at the surface to $250-400 \mu \mathrm{mol}^{-1}$ at $20 \mathrm{~cm}$ depth. Slightly higher concentrations were observed at $1-5 \mathrm{~cm}$ depth on the right shore (station e) and at 10-20 cm depth on the left shore (station E2). Higher cross-section variations were observed in the intermediate Aulne Estuary (Fig. 3B). As observed in February, porewater $\mathrm{Si}(\mathrm{OH})_{4}$ concentrations reached more than $800 \mu \mathrm{mol} \mathrm{l}^{-1}$ at $3-5 \mathrm{~cm}$ depth in May. While porewater $\mathrm{Si}(\mathrm{OH})_{4}$ concentrations were similar at $0-$ $5 \mathrm{~cm}$ depth across the section in the intermediate Aulne Estuary, they varied between 100 and $600 \mu \mathrm{mol} \mathrm{l}^{-1}$ down to $5 \mathrm{~cm}$ depth. Similar to station E2, the highest concentrations were measured in left and right subtidal shores (400-1000 $\mu \mathrm{mol} \mathrm{l}^{-1}$ at stations A2 and e). $\int \mathrm{Si}(\mathrm{OH})_{4}$ values were not significantly different at the stations of the cross-section and at station E2 in the Elorn Estuary, but were slightly lower at the stations of the cross-section in the Aulne Estuary than at station A2 (Table 3). As for the longitudinal transect, the CV was lower in the Elorn Estuary (6-17\%) than in the Aulne Estuary (42-59\%; Table 2). The CV was slightly higher along the cross-section than on the left subtidal shore in the Elorn Estuary. In the Aulne Estuary, the subtidal shore metre variability at station A2 was even higher than the cross-section variability.

Comparisons between channel and subtidal shore $\mathrm{Si}(\mathrm{OH})_{4}$ concentrations in porewaters at different stations and seasons are shown in Fig. 4. Porewater $\mathrm{Si}(\mathrm{OH})_{4}$ concentrations at $0-10 \mathrm{~cm}$ depth were lower in the channel than in subtidal shores in both estuaries. In surficial sediments, similar porewater $\mathrm{Si}(\mathrm{OH})_{4}$ concentrations in the channel and the subtidal shore were observed in

\section{A. Elorn Estuary}

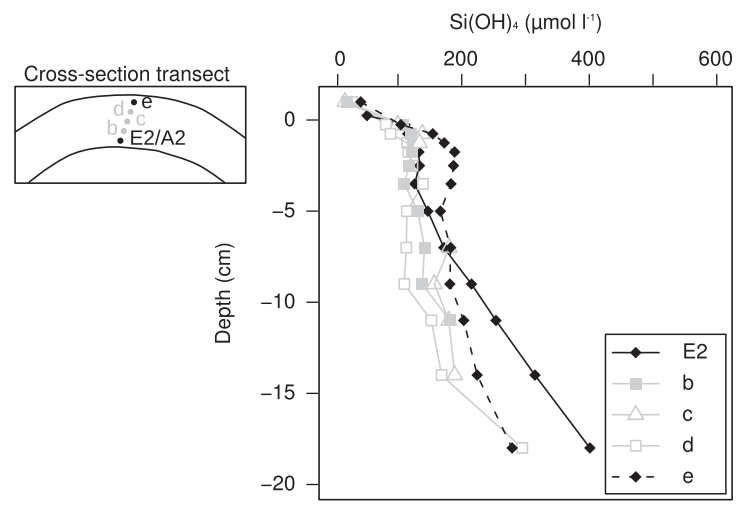

\section{B. Aulne Estuary}

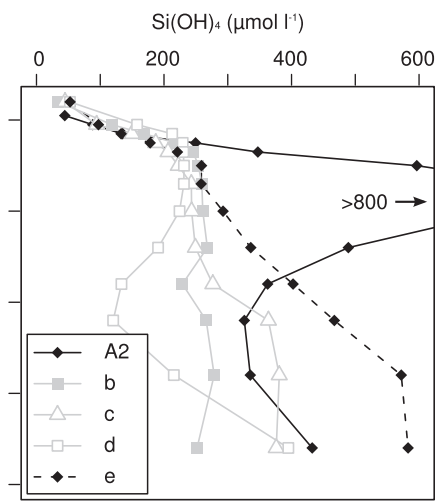

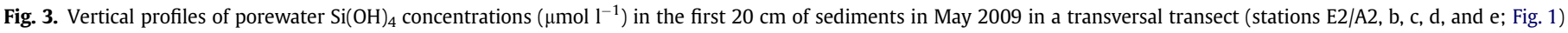
performed in intermediate Elorn and Aulne estuaries. 

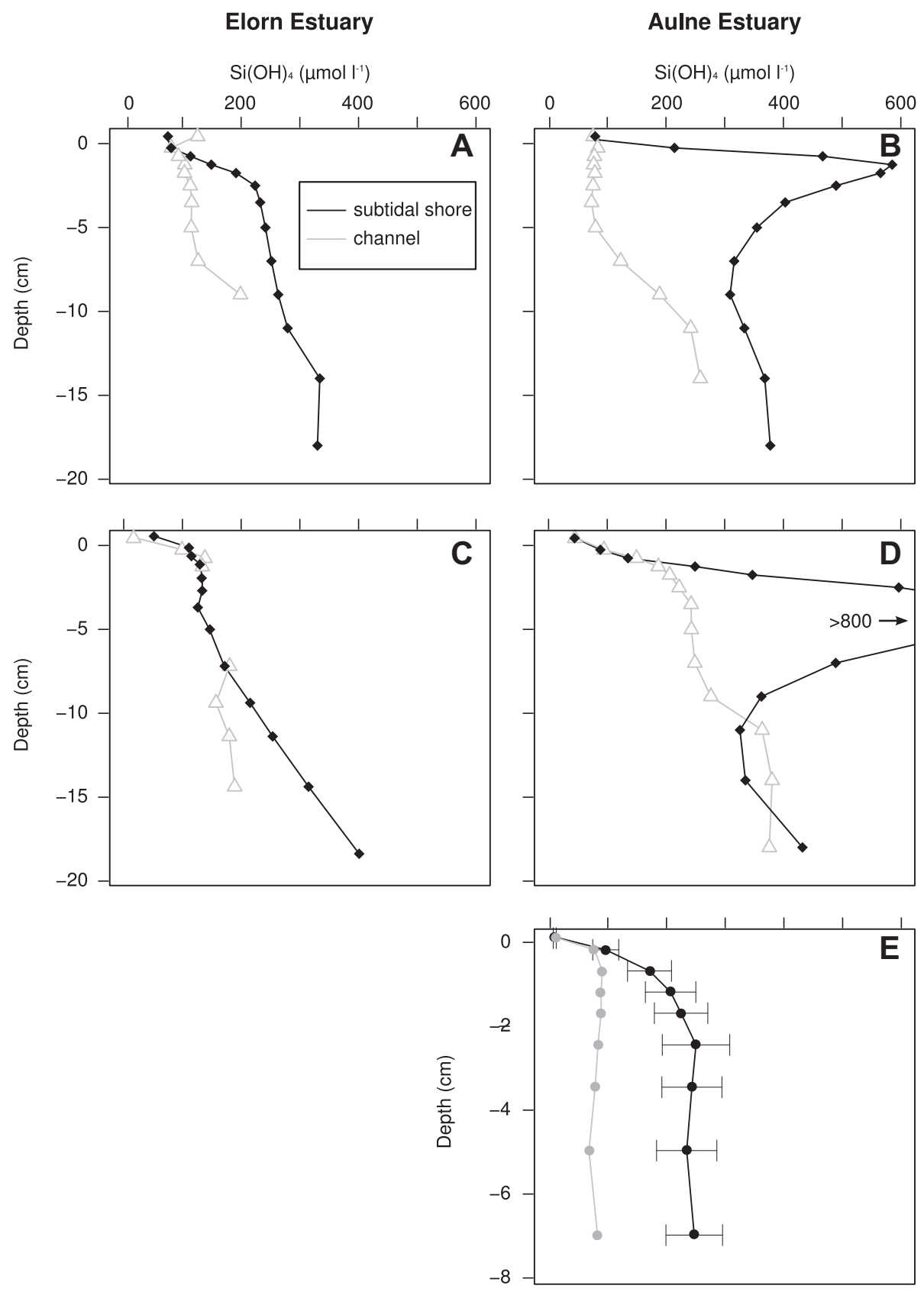

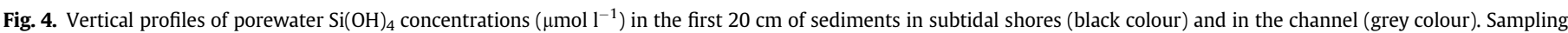

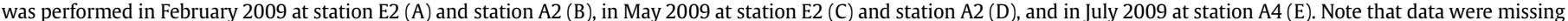

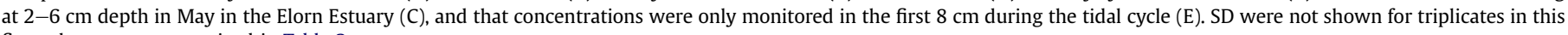
figure but were summarized in Table 2 .

the intermediate Elorn Estuary in February (Fig. 4A) and Aulne Estuary in May (Fig. 4D). Higher differences in porewater $\mathrm{Si}(\mathrm{OH})_{4}$ concentrations between the channel and the subtidal shore were observed in the intermediate Aulne Estuary in February (Fig. 4B), in the intermediate Elorn Estuary in May (Fig. 4C), and in the outer Aulne Estuary in July (Fig. 4E). A slight but significant correlation was found between porewater $\mathrm{Si}(\mathrm{OH})_{4}$ concentrations and the proportion of fine particles $(\%<63 \mu \mathrm{m})$ in surficial sediments of the whole dataset (Pearson, $r^{2}=0.35, p<0.0001$ ).

\subsubsection{Tidal variability}

Tidal cycles were visible through increasing salinity and water depth and decreasing bottom water temperature and $\mathrm{Si}(\mathrm{OH})_{4}$ concentrations from low tide to high tide, with the inverse trend until the next low tide (Fig. 5A). In sediments, variations in porewater $\mathrm{Si}(\mathrm{OH})_{4}$ concentrations were also observed over tidal cycles (Fig. 5B). Porewater $\mathrm{Si}(\mathrm{OH})_{4}$ concentrations at $0-8 \mathrm{~cm}$ depth increased from low to high tide and then decreased until low tide. The CV was high (29-32\%; Table 2 ) and $\int \mathrm{Si}(\mathrm{OH})_{4}$ variations were significant over the tidal cycle (Table 3 ).

\subsection{Benthic variability at estuarine and seasonal scales}

\subsubsection{Intra- and inter-estuary variations}

Overall porewater $\mathrm{Si}(\mathrm{OH})_{4}$ concentrations were lower in the Elorn Estuary than in the Aulne Estuary (Fig. 6). Deep $\mathrm{Si}(\mathrm{OH})_{4}$ 


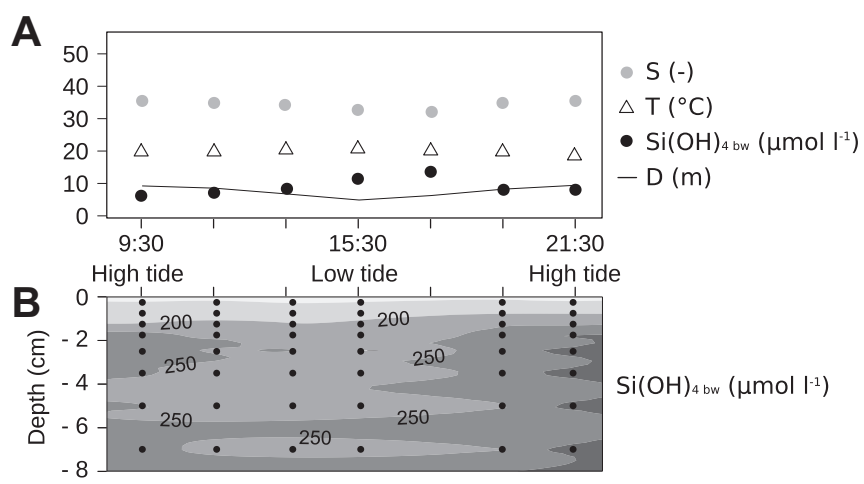

Fig. 5. Salinity $\mathrm{S}(-)$, temperature $T\left({ }^{\circ} \mathrm{C}\right)$, and $\mathrm{Si}(\mathrm{OH})_{4}$ concentrations $\mathrm{Si}(\mathrm{OH})_{4}$ bw $\left(\mu \mathrm{mol} \mathrm{l}^{-1}\right)$ of bottom waters, water depth $\mathrm{D}(\mathrm{m})(\mathrm{A})$, and vertical profiles of porewater $\mathrm{Si}(\mathrm{OH})_{4}$ concentrations $\left(\mu \mathrm{mol} \mathrm{l^{-1 }}\right.$ ) in the first $20 \mathrm{~cm}$ of sediments (B) every $2 \mathrm{~h}$ during $12 \mathrm{~h}$ in July 2009. concentrations (at $20 \mathrm{~cm}$ depth) slightly increased from upper to outer Elorn Estuary (Fig. 6; E1, E2, E3). Regardless of the season, porewater $\mathrm{Si}(\mathrm{OH})_{4}$ concentrations were stable between 0 and $20 \mathrm{~cm}$ depth at station E1. At station $\mathrm{E} 2, \mathrm{Si}(\mathrm{OH})_{4}$ profiles were characterized by a depletion at intermediate depths $(5-15 \mathrm{~cm}$ depth), while at station E3, typical asymptotic $\mathrm{Si}(\mathrm{OH})_{4}$ profiles were observed. No trend was observed however along the Aulne Estuary (Fig. 6; A1, A2, A3). At stations A1, A2 (in July and October) and $\mathrm{A} 3, \mathrm{Si}(\mathrm{OH})_{4}$ profiles exponentially increased with depth, except the very different profiles observed in February and May at station A2 (described in Section 3.1).

Despite higher porewater $\mathrm{Si}(\mathrm{OH})_{4}$ concentrations in the Aulne Estuary, a similar range of porewater $\mathrm{Si}(\mathrm{OH})_{4}$ concentrations was, however, observed at saline stations E3 and A3 (300$\left.600 \mu \mathrm{mol} \mathrm{l}^{-1}\right)$. $\int \mathrm{Si}(\mathrm{OH})_{4}$ values varied between stations and seasons and with the interaction of these two factors (ANOVA; Table 4). Tukey post-hoc tests (not shown) indicated significantly lower $\int \mathrm{Si}(\mathrm{OH})_{4}$ values at stations E1, E2, and E3 than at stations A1
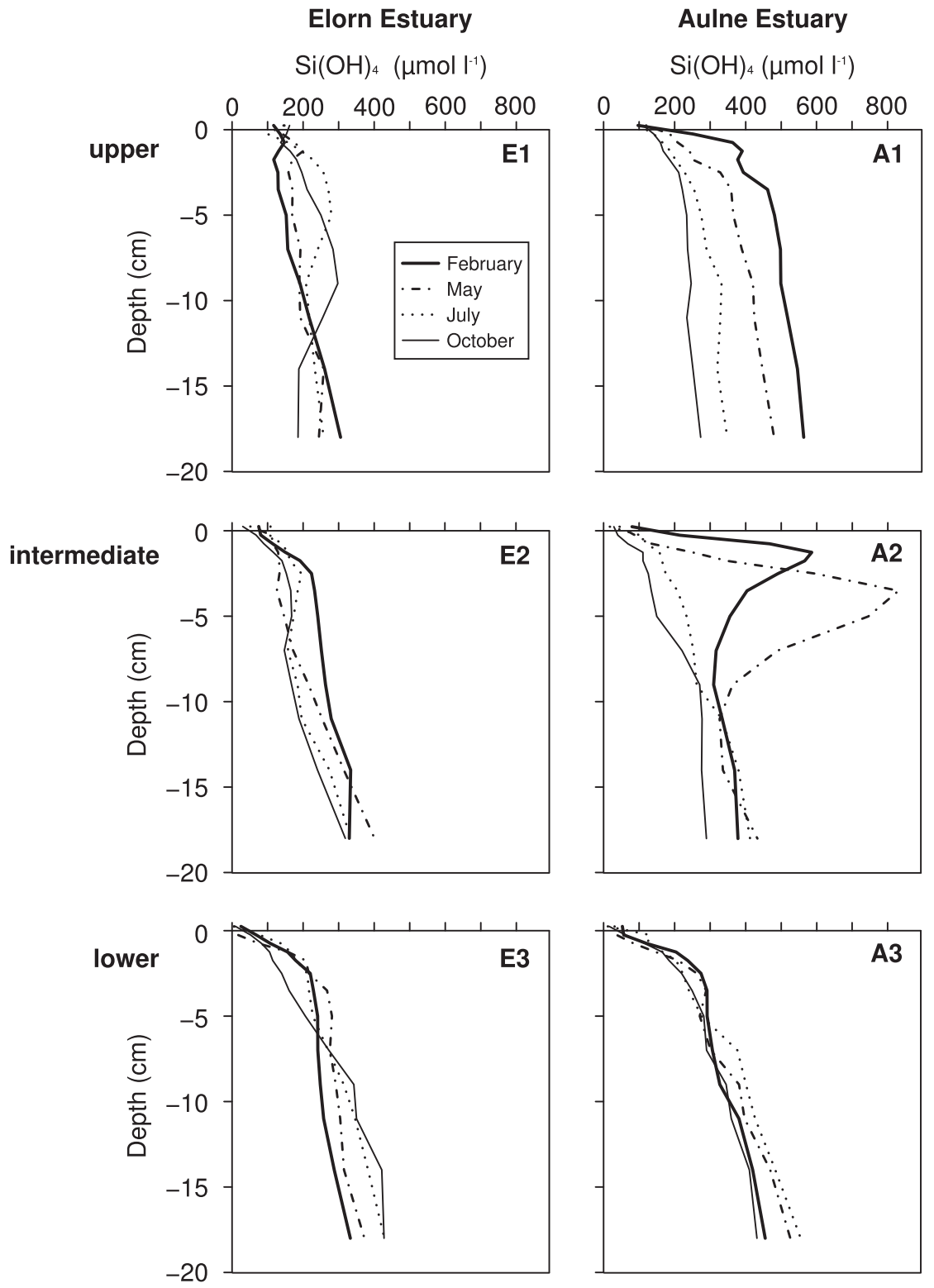

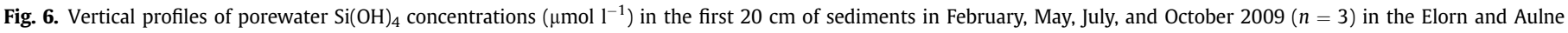
estuaries (stations E1, E2, E3, A1, A2, and A3). SD were not shown in this figure but were summarized in Table 2. 
Table 4

Results of statistical tests for seasonal variations of $\int \mathrm{Si}(\mathrm{OH})_{4}$ along Elorn and Aulne estuaries. The station and season factors and the combination of these two factors were tested on the $\int \mathrm{Si}(\mathrm{OH})_{4}$ dataset. ANOVA or Kruskal-Wallis test were chosen depending on dataset criteria described in Section 2.5. Abbreviations: $\mathrm{df}=$ degree of freedom; $F$ and $K^{2}=$ statistical value for each statistical test; $p=p$ value.

\begin{tabular}{lllll}
\hline Factors & Statistical test & df & $F$ or $K^{2}$ & $p$ \\
\hline Elorn & Kruskal-Wallis & 2 & 7.49 & $\mathbf{0 . 0 2}$ \\
Salinity gradient & Kruskal-Wallis & 3 & 1 & 0.8 \\
Season & Kruskal-Wallis & - & - & - \\
Salinity gradient $\times$ season & & & & \\
Aulne & ANOVA & 2 & 1.04 & 0.37 \\
Salinity gradient & ANOVA & 3 & 6.44 & $\mathbf{0 . 0 0 2}$ \\
Season & ANOVA & 6 & 2.68 & $\mathbf{0 . 0 4}$ \\
Salinity gradient $\times$ season & A
\end{tabular}

Significant differences $(p<0.05)$ are indicated by bold values.

and $\mathrm{A} 2$, but no significant differences with station $\mathrm{A} 3$. $\int \mathrm{Si}(\mathrm{OH})_{4}$ was significantly lower at station E2 than at E3 (Kruskal-Wallis and multiple comparison test), but no spatial differences were observed in the Aulne Estuary.

Very high pelagic $\mathrm{aSiO}_{2}$ concentrations were also found in February in upper estuaries (Fig. 7). They ranged between 23$56 \mu \mathrm{mol} \mathrm{l}^{-1}$ and $28-77 \mu \mathrm{mol} \mathrm{l}^{-1}$ at salinity $0-5$ in the upper Elorn and Aulne estuaries, respectively.

\subsubsection{Seasonal variations}

The lowest seasonal variations in $\mathrm{Si}(\mathrm{OH})_{4}$ profiles were observed in the Elorn Estuary (stations E1, E2, and E3) and at station A3 compared to stations A1 and A2 (Fig. 6). Seasonal variations were not significant in the Elorn Estuary (ANOVA; Table 4). The shape of $\mathrm{Si}(\mathrm{OH})_{4}$ profiles however varied at station E2, with an increase of $\mathrm{Si}(\mathrm{OH})_{4}$ depletion depth from May $(5 \mathrm{~cm}$ depth) to October $(15 \mathrm{~cm}$ depth). In contrast, high and significant seasonal variations of $\int \mathrm{Si}(\mathrm{OH})_{4}$ were observed in the Aulne Estuary (Kruskal-Wallis; Table 4). At stations $\mathrm{A} 1$ and $\mathrm{A} 2, \int \mathrm{Si}(\mathrm{OH})_{4}$ values were significantly lower in October than in February and May (Tukey posthoc test, not shown).

\subsection{Comparison of benthic variation amplitudes at the different scales}

Fig. 8 shows the similarity and difference between metre, longitudinal, cross-section and seasonal variations of $\int \mathrm{Si}(\mathrm{OH})_{4}$ in intermediate Elorn and Aulne estuaries. In the Elorn Estuary,

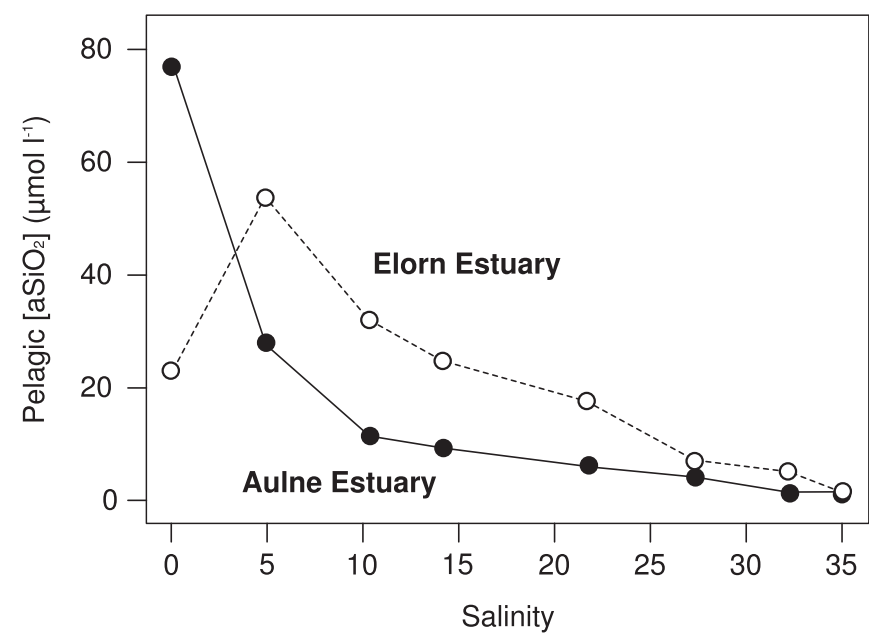

Fig. 7. Pelagic $\mathrm{aSiO}_{2}$ concentrations $\left(\mu \mathrm{mol} \mathrm{l} \mathrm{l}^{-1}\right.$ ) and benthic surficial $\mathrm{aSiO}_{2}$ concentrations (\%) in February 2009 in the Elorn Estuary (A), and in the Aulne Estuary (B). $\int \mathrm{Si}(\mathrm{OH})_{4}$ measured in February was different from other seasons, but seasonal variability between May, July, and October was low (Fig. 8A). The variability of $\int \mathrm{Si}(\mathrm{OH})_{4}$ along longitudinal transect in February was lower than seasonal variations. The low seasonal variations, however, did not distinguish seasonal and cross-section variations. Even if $\int \mathrm{Si}(\mathrm{OH})_{4}$ was similar from May to October, it is important to note that the shape of the profiles were different depending on seasons (Fig. 6). In the intermediate Aulne Estuary, seasonal variations of $\int \mathrm{Si}(\mathrm{OH})_{4}$ were significant (Table 4) but were lower than triplicate, longitudinal and cross-section variability (Fig. 8B). As for the Elorn Estuary, $\int \mathrm{Si}(\mathrm{OH})_{4}$ was different in February compared to the other seasons. One season (May) was characterized by a high dispersion of triplicates in the whole cluster. This heterogeneity was also observed in the cross-section transect, indicating high metre and pluri-metre variability in the intermediate Aulne Estuary. In both estuaries, July and October were indicated with always one replicate more distant from the 2 others.

\section{Discussion}

\subsection{Factors controlling the variability of porewater $\mathrm{Si}(\mathrm{OH}) 4$} concentrations in macrotidal estuaries

\subsubsection{Analytical precision}

The coefficient of variation $(\mathrm{CV})$ of porewater $\mathrm{Si}(\mathrm{OH})_{4}$ concentrations ranges between 1 and 59\%, regardless of the scale studied in the Elorn and Aulne estuaries (Table 2). These values are always higher compared to the precision of the analytical method $(0.5 \%)$, indicating that variability caused by analytical methods is negligible compared to the field variability. This confirmed the observations made in the Indian River Estuary in Florida, where laboratory variability was $0.3 \%$ while metre benthic heterogeneity reached 40\% (Montgoméry et al., 1979).

\subsubsection{Reaction and transport processes}

4.1.2.1. Benthic properties controlling asymptotic $\mathrm{Si}(\mathrm{OH})_{4}$ concentrations. Despite variation at the different scales in the Elorn and Aulne estuaries, similar porewater profiles and asymptotic $\mathrm{Si}(\mathrm{OH})_{4}$ concentrations (Figs. 3A and 6-station E2) suggest homogeneous benthic properties at metre and longitudinal scales. The main benthic sediment and porewater properties expected to be homogeneous at a small scale $(1-100 \mathrm{~m})$ are $\mathrm{pH}$, aluminium and detrital contents, as well as specific sediment surface area, which are known to strongly control deep porewater $\mathrm{Si}(\mathrm{OH})_{4}$ concentrations (Dixit et al., 2001; Dixit and Van Cappellen, 2002). At larger scale $(\mathrm{km})$, the small increase in asymptotic $\mathrm{Si}(\mathrm{OH})_{4}$ concentrations from the upper to the lower Elorn Estuary is consistent with decreasing aluminium and detrital contents in fresh to marine sediments (Hydes and Liss, 1976; Odum, 1984). The low seasonal variations of asymptotic $\mathrm{Si}(\mathrm{OH})_{4}$ concentrations observed in the Elorn Estuary are explained by the relative stability of deep sediment properties compared to surficial ones (Berner, 1980). The low intra-estuary variations and the high seasonal variations in the Aulne Estuary suggest however that benthic variability in deep $\mathrm{Si}(\mathrm{OH})_{4}$ concentrations might be less constrained by deep sediment properties than by other processes described below.

4.1.2.2. Hydrodynamic regime. The lower porewater $\mathrm{Si}(\mathrm{OH})_{4}$ concentrations observed in the channel compared to subtidal shores, especially in the top $5 \mathrm{~cm}$ of the sediment (Fig. 4), was explained by sediment resuspension. Wave and tidal currents indeed lead to intense mixing, which strongly enhances diffusive transport and generates low porewater $\mathrm{Si}(\mathrm{OH})_{4}$ concentrations in upper estuarine sediments (e.g. until $3-5 \mathrm{~cm}$ depth in the Scheldt Estuary; Vanderborght et al., 1977; Rebreanu, 2009). The smallest 
A. Intermediate Elorn Estuary

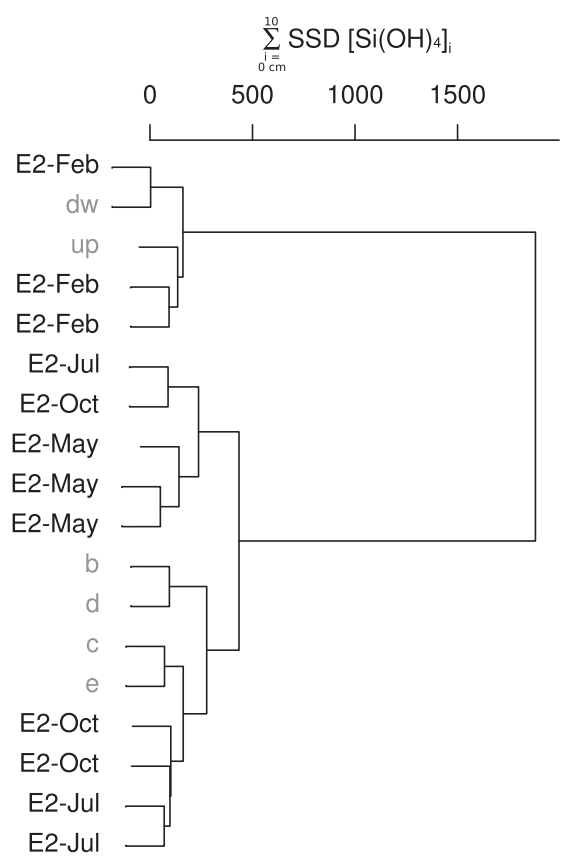

B. Intermediate Aulne Estuary

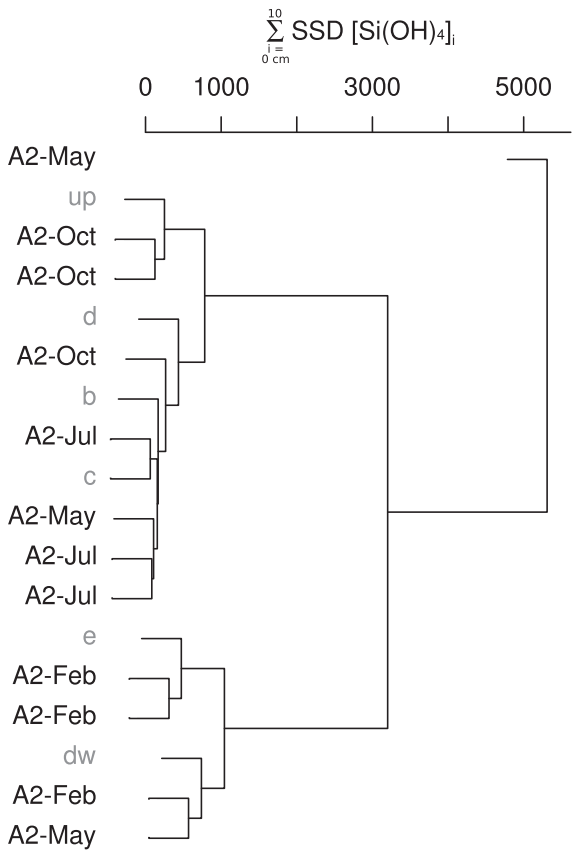

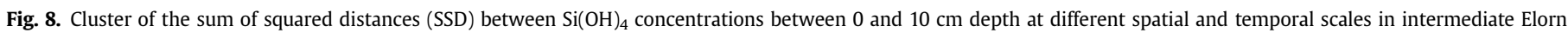
Estuary (A), and Aulne Estuary (B). See Fig. 1 and Table 1 for abbreviations.

differences in porewater $\mathrm{Si}(\mathrm{OH})_{4}$ concentrations between the channel and the subtidal shore sediments - and the low CV of $\int \mathrm{Si}(\mathrm{OH})_{4}-$ in May compared to February, can be explained by the lower river discharge which decreases sediment resuspension, and thus prevents the decrease in porewater $\mathrm{Si}(\mathrm{OH})_{4}$ concentrations in the channel in May. Resuspension must have important consequences in increasing $\mathrm{Si}(\mathrm{OH})_{4}$ export to pelagic waters, either through the direct enhancement of benthic fluxes, or through the increase of $\mathrm{aSiO}_{2}$ dissolution by keeping $\mathrm{Si}(\mathrm{OH})_{4}$ concentrations from equilibrium with $\mathrm{aSiO}_{2}$ dissolution. Resuspension thus mainly creates spatial heterogeneity in estuarine areas characterized by high tidal currents, and especially in the channel which leads to potential cross-section heterogeneity.

The overall positive correlation between $\mathrm{Si}(\mathrm{OH})_{4}$ concentrations and the proportion of fine particles $(\%<63 \mu \mathrm{m})$ in surficial sediments $\left(r^{2}=0.35, p<0.0001\right)$ suggests that lower benthic $\mathrm{Si}(\mathrm{OH})_{4}$ concentrations - and thus $\mathrm{aSiO}_{2}$ concentrations - are associated with coarser sediments, which has already been suggested in the Scheldt Estuary (Rebreanu, 2009). These observations reinforce that sediment redistribution and sorting is important in determining the spatial variability of benthic $\mathrm{Si}$ contents. Even if $\mathrm{aSiO}_{2}$ have been deposited with sediment particles - as also observed in intertidal marshes (Struyf et al., 2006) - the low correlation however highlights that other processes than sediment grain size control benthic $\mathrm{Si}(\mathrm{OH})_{4}$ concentrations, e.g. $\mathrm{aSiO}_{2}$ quantity and quality.

4.1.2.3. Biological processes. In addition to the role of sediment properties and diffusive transport in porewater $\mathrm{Si}(\mathrm{OH})_{4}$ distributions, biological processes (e.g. bioirrigation) play an important role in the modulation of benthic $\mathrm{Si}(\mathrm{OH})_{4}$ concentrations. The exponential increase in porewater $\mathrm{Si}(\mathrm{OH})_{4}$ concentrations - commonly observed in the absence of bioirrigation (McManus et al., 1995) was consistent with the absence of benthic fauna in the intermediate Aulne Estuary (station A2; Emma Michaud, pers. comm.). A typical example of the role of bioirrigation however occurs in the intermediate Elorn Estuary (station E2; Fig. 6). Porewater $\mathrm{Si}(\mathrm{OH})_{4}$ concentrations are characterized by $\mathrm{Si}(\mathrm{OH})_{4}$ depletion in sediments at this station, where the depletion depth increases seasonally from 5 to $15 \mathrm{~cm}$ depth. The shape of porewater $\mathrm{Si}(\mathrm{OH})_{4}$ profiles is typical of sediments where transport processes induced by bioirrigation may overcome the importance of dissolution (Aller, 1980). Regardless the irrigation strategies, these depletions are consistent with the enhancement of diffusive transport of porewaters - which is similar to diffusive transport mediated by sediment resuspension and/or non-local transport of water (Mermillod-Blondin et al., 2005). Modelling the benthic Si cycle at this station (Raimonet, 2011), together with direct identification of benthic fauna (Michaud et al., in prep.) have confirmed the role of benthic fauna in producing these profiles. Bioirrigation often increases sediment oxygenation (Waldbusser et al., 2004), which favours the degradation of benthic organic matter, and in turn, the dissolution of benthic $\mathrm{aSiO}_{2}$. By flushing burrows, bioirrigation prevents the enhancement of porewater concentrations induced by dissolution (Boudreau and Marinelli, 1994). Decreasing porewater $\mathrm{Si}(\mathrm{OH})_{4}$ concentrations and keeping them away from equilibrium - increases dissolution rates. Bioirrigation thus simultaneously enhances the dissolution of $\mathrm{aSiO}_{2}$ and decreases porewater $\mathrm{Si}(\mathrm{OH})_{4}$ concentrations due to the net export of porewaters to bottom waters.

4.1.2.4. Interaction of processes. The different processes described above simultaneously impact benthic $\mathrm{Si}(\mathrm{OH})_{4}$ concentrations, as highlighted in our tidal cycle. Even if tidal variations in porewater $\mathrm{Si}(\mathrm{OH})_{4}$ concentrations are expected to be limited in cohesive sediments - as they are generally dominated by diffusive rather than advective processes (Boudreau, 1997) - changes in $\mathrm{Si}(\mathrm{OH})_{4}$ concentrations were observed over $8 \mathrm{~cm}$ depth (Fig. 5). Resuspension is often limited to the first $3-5 \mathrm{~cm}$ (Vanderborght et al., 1977; Rebreanu, 2009). Tidal variations observed down to $8 \mathrm{~cm}$ depth suggest that either stronger currents are present in subtidal shores (which is not expected in subtidal sediments), or that other processes - detailed above - simultaneously occur. 
Rapid and deep variations in $\mathrm{Si}(\mathrm{OH})_{4}$ concentrations have already been related to tidal pumping in permeable sandy and coastal sediments, which leads to the vertical transport of porewaters over several centimetres (Shum and Sundby, 1996; Jahnke et al., 2003; Chatelain, 2010). A recent modelling study highlighted that tidal pumping occurs in cohesive sediments, in particular close to the creekbank (Wilson and Morris, 2012). This model was applied to a shallow estuary ( $<3 \mathrm{~m}$ depth) characterized by a mean tidal amplitude of $1.4 \mathrm{~m}$, confirming that shallow and macrotidal estuaries could be much more impacted by such tidal pumping than expected. Tidal pumping has also been highlighted in macrotidal intertidal mudflats where advective fluxes were 400 times higher than diffusive fluxes when water rose (Leynaert et al., 2011). It is therefore reasonable to attribute the deep variations of porewater $\mathrm{Si}(\mathrm{OH})_{4}$ concentrations over tidal cycles to tidal pumping.

As tidal pumping occurs in these muddy sediments, porewater $\mathrm{Si}(\mathrm{OH})_{4}$ concentrations are expected to be higher at low tide and not at high tide (Fig. 5). The presence of burrows built by benthic fauna is hypothesized to enhance the transport of porewaters and/ or bottom waters out and/or into benthic sediments (Aller, 1980; Berner, 1980; Stieglitz et al., 2000). Aller (1980) indeed showed that burrows lead to significant decreases in porewater $\mathrm{Si}(\mathrm{OH})_{4}$ concentrations. Between high and low tides, the flushing of burrows with bottom waters might have led to lower porewater $\mathrm{Si}(\mathrm{OH})_{4}$ concentrations. Localized lower $\mathrm{Si}(\mathrm{OH})_{4}$ concentrations observed at 4,6 , or $8 \mathrm{~cm}$ depth (Fig. 5) particularly highlight burrows localized at specific depths, as it has been shown in permeable sediments (Meysman et al., 2006). As the Elorn and Aulne estuaries are shallow ( $<10 \mathrm{~m}$ depth) and characterized by a macrotidal regime, changes in water column height and current speed are very important at tidal scales, strengthening the potential role of tidal pumping and resuspension in bioirrigated sediments of macrotidal estuaries. We hypothesize that these processes significantly control $\mathrm{Si}(\mathrm{OH})_{4}$ concentrations and benthic fluxes: (1) at the tidal scale, in particular in shallow macrotidal estuaries, due to wide tidal amplitude; and (2) at the seasonal scale, due to the seasonal variation of benthic macrofauna (maximal activity and biomass during summer) and temperature (maximal production and dissolution in summer).

Benthic reaction and transport processes and their controlling factors thus play an important role in controlling porewater $\mathrm{Si}(\mathrm{OH})_{4}$ concentrations and their variability at different scales. However, the $\mathrm{aSiO}_{2}$ transported by the river and estuary, as well as the factors that control the area of $\mathrm{aSiO}_{2}$ deposition and their variability, also play a role in the distribution of porewater $\mathrm{Si}(\mathrm{OH})_{4}$ concentrations in estuarine sediments.

\subsubsection{Quantity and quality of $\mathrm{aSiO}_{2}$ inputs}

Up to $80 \mu \mathrm{mol} \mathrm{l}^{-1}$ of $\mathrm{aSiO}_{2}$ were measured in fresh waters in the upper Aulne Estuary in February (Fig. 7). These concentrations are similar to those of large rivers like the Amazon River $\left(74 \mu \mathrm{mol} \mathrm{l}^{-1}\right)$ and high compared to most of the rivers $\left(2.9-38 \mu \mathrm{mol} \mathrm{l}^{-1}\right.$; Conley, 1997; review in Vieillard et al., 2011). This confirms that although Si has long been thought to flow from rivers mostly in its dissolved form (Tréguer et al., 1995), inputs of $\mathrm{Si}$ in the form of particulate amorphous silica $\left(\mathrm{aSiO}_{2}\right)$ may be significant (Conley, 1997; Smis et al., 2010; Tréguer and De La Rocha, 2013). The rapid and concave decrease in pelagic $\mathrm{aSiO}_{2}$ concentrations along the salinity gradient highlights a transient increase in $\mathrm{aSiO}_{2}$ concentrations in freshwaters as already demonstrated through a modelling approach (Scheldt Estuary; Regnier et al., 1998), and estuarine deposition of $\mathrm{aSiO}_{2}$ (Danube Delta; Ragueneau et al., 2002b). The high concentration in pelagic $\mathrm{aSiO}_{2}$ and its deposition may explain our observations of these subsurface maxima in the porewaters in the meander of the intermediate Aulne Estuary, as detailed below.
4.1.3.1. Control of the hydrodynamic regime on $\mathrm{aSiO}_{2}$ deposition. The high $\mathrm{aSiO}_{2}$ concentrations in the upper Aulne Estuary in February are associated with high winter river discharge, which leads to the downward displacement of fluid muds, associated to the maximal turbidity zone (MTZ; Hermann and Heip, 1999; Meire et al., 2005), close to station A2. The transport of MTZ might lead to the deposition of suspended matter - including $\mathrm{aSiO}_{2}-$ in meanders located close to the MTZ, in the intermediate estuary (this study). River discharge variability - which can be essential in maintaining biodiversity and stability of the ecosystem (Poff, 2009) - is thus also important in determining the spatial and temporal variability of sediment deposition, and thus of benthic Si contents. During high river discharge, the quantity of exported particulate matter and $\mathrm{aSiO}_{2}$ is higher and the MTZ moves downward in the estuary, which contributes to the settlement of particles from the MTZ in the meander.

The presence of this high subsurface maximum in February and May at station $\mathrm{A} 2$, suggests that the deposition of $\mathrm{aSiO}_{2}$ is localized in the point bar, the internal part of the meander (Fig. 6, station A2). The contribution of groundwater (e.g. Wilson and Morris, 2012) was discarded by constant salinity over sediment depth in February and May. By accumulating sediments, point bars are potential recorders of the seasonality of river and estuarine loads, e.g. $\mathrm{aSiO}_{2}$, organic matter, and other particulate loads, from the catchment, river and estuary. The seasonal evolution of $\mathrm{Si}(\mathrm{OH})_{4}$ profiles highlights deposition and erosion dynamics in point bars. The deepening of the subsurface maximum indicates a deposition rate of $\sim 2 \mathrm{~cm}$ between February and May (i.e. $\sim 0.5-0.6 \mathrm{~cm} \mathrm{month}^{-1}$ ). This rate is particularly high for coastal ecosystems and characteristic of preferential deposition areas (McKee et al., 1983). This is thus consistent with generally favoured deposition in point bars. In July and October, the absence of soft sediments, however, highlights sediment erosion in the point bar between May and July, confirming our hypothesis that transient deposition and erosion events occur at this station. Erosion - which has occurred in late spring (after May), probably after a small storm event in June - indicates that the potential storage of $\mathrm{aSiO}_{2}$ in intermediate point bars can either be translocated, which may have important implications for the ecological functioning of estuarine ecosystems. The highest spatial heterogeneity at a 1$100 \mathrm{~m}$ scale, and even at seasonal scales, is moreover observed in the meander, which highlights localized deposition and strong heterogeneity associated to high dynamic regimes. Studying deposition-erosion dynamics in estuaries, and more especially in meanders, is thus essential to investigate transient retention in estuaries.

4.1.3.2. Quality of $\mathrm{aSiO}_{2}$. Seasonal changes in porewater $\mathrm{Si}(\mathrm{OH})_{4}$ concentrations in the point bar of an intermediate estuarine meander also indicate the seasonality of the quality of $\mathrm{aSiO}_{2}$ transported into the estuary. The high subsurface $\mathrm{Si}(\mathrm{OH})_{4}$ concentrations observed at station A2 in February and May is most likely due to transient deposition of highly reactive $\mathrm{aSiO}_{2}$ that dissolved quickly in the subsurface sediment layers. Dissolution rates must be sufficiently high to sustain such subsurface maxima. In the Danube Delta (Becquevort et al., 2002; Ragueneau et al., 2002b) or in the Scheldt Estuary (Roubeix et al., 2008), it has been demonstrated that $\mathrm{aSiO}_{2}$ dissolution is closely coupled to the microbial degradation of organic matter. Bacteria are very efficient at degrading the organic matrix that is associated with diatom frustules or any other form of $\mathrm{aSiO}_{2}$, exposing the silica surfaces to surrounding waters and thus increasing the dissolution of $\mathrm{aSiO}_{2}$ (Bidle and Azam, 1999). Hence, the effect of bacteria, in particular in the MTZ, has been shown to overwhelm the effect of salinity on dissolution in the MTZ of the Scheldt Estuary (Roubeix et al., 2008). 
Highly reactive $\mathrm{aSiO}_{2}$ in estuarine sediments in February and May either results from the deposition of: (1) a diatom bloom; or (2) allochtonous winter loads. Even if diatoms are often characterized by higher dissolution rates than sedimentary and degraded $\mathrm{aSiO}_{2}$ (Rickert et al., 2002), the deposition of a diatom bloom grown during the previous year is not a likely explanation. A loss in reactivity and solubility of $\mathrm{aSiO}_{2}$ is indeed observed over time due to coatings or detritus in sediments, and leads to lower porewater $\mathrm{Si}(\mathrm{OH})_{4}$ concentrations (Van Cappellen and Qiu, 1997a,b; Rickert et al., 2002). The origin of reactive $\mathrm{aSiO}_{2}$ observed in surficial sediments in the intermediate Aulne Estuary is consistent with high pelagic $\mathrm{aSiO}_{2}$ concentrations in the upper Aulne Estuary in February, providing evidence of allochtonous $\mathrm{aSiO}_{2}$ inputs to the estuary. Loads of $\mathrm{aSiO}_{2}$ after the autumn may, at least partly, be associated with the export of terrestrial or tidal marsh detritus, such as dead plants or phytoliths (Smis et al., 2010; Querné, 2011). As phytoliths have not already suffered dissolution loops, they are generally characterized by higher solubility (Fraysse et al., 2009), and higher dissolution rates than benthic $\mathrm{aSiO}_{2}$ (Querné, 2011).

Our results indicate that riverine $\mathrm{aSiO}_{2}$ can be very reactive and lead to high porewater $\mathrm{Si}(\mathrm{OH})_{4}$ concentrations in local deposition areas. $\mathrm{aSiO}_{2}$ is even shown to be very reactive during winter, while winter dissolution is often assumed to be lower due to the absence of primary production, less bacteria and low temperature limiting biological activities. This suggests that a better quantitative and qualitative characterization of riverine and estuarine $\mathrm{aSiO}_{2}$ is needed to better understand its fate in estuaries. This will help us in understanding better the temporal and spatial variability of pelagic and benthic properties and processes; such information is crucial when discussing, at different scales, temporary or permanent retention of $\mathrm{Si}$ along the land ocean continuum.

\subsection{Implications of this benthic variability for local ecological studies and perspectives for regional and global biogeochemical approaches of Si retention}

This study has different implications from local to global scales, either from the ecological or biogeochemical point of view. At the local scale, sampling at various temporal and spatial scales is not often performed in estuarine studies. It is however essential to study small scale variations as spatial heterogeneities can sometimes prevent to study seasonal trends (Bay of Biscay; Mouret, 2009). The absence of significant differences in porewater $\mathrm{Si}(\mathrm{OH})_{4}$ concentrations along and across estuarine sections in the linear Elorn Estuary (Table 3) shows that triplicates in subtidal shores are representative of porewater $\mathrm{Si}(\mathrm{OH})_{4}$ concentrations in a section of 100-1000 m scale in small linear estuaries. The coefficient of variation (CV) of porewater $\mathrm{Si}(\mathrm{OH})_{4}$ concentrations in the Elorn Estuary (CV of triplicates $=2-25 \%$; Table 2 ) is in the range of values observed in other estuaries (10-40\%; Matisoff et al., 1975; Montgoméry et al., 1979). The smaller variability of porewater $\mathrm{Si}(\mathrm{OH})_{4}$ concentrations in the Elorn Estuary compared to the Aulne Estuary (1-59\%; Table 2) suggests that linear estuaries might have more homogeneous porewater properties, implying that a discrete sampling along the salinity gradient in small linear estuaries might be enough to investigate variations along estuarine salinity gradients.

The lower variability at metre and plurimetre scales in the linear Elorn Estuary compared to the meandering Aulne Estuary has implications for local or regional modelling studies (e.g. on eutrophication), which use available, and often sparse, data to calibrate and/or validate models. When transposing small spatial variability to data uncertainty, this study highlights that data obtained along salinity gradients of linear estuaries are associated to lower uncertainty (2-25\%) than those of meandering estuaries (1-59\%), providing more confidence in model calibration and/or results in the linear systems. These quantifications are useful to estimate uncertainty during upscaling, but also to prevent significant errors incurred by failing to resolve spatial and temporal variation (Swaney and Giordani, 2007; Swaney et al., 2012). Webster et al. (2000) even highlighted that inappropriate temporal and spatial averaging could lead to errors of up to $30 \%$ and $100 \%$ in estuarine budgets.

The high porewater $\mathrm{Si}(\mathrm{OH})_{4}$ concentrations observed in these estuaries, especially in the upper and intermediate Aulne Estuary, and the transient retention in point bars confirm that continental margins, and more precisely estuaries, constitute significant areas for Si retention. From an ecological point of view, this indicates a potential stock of $\mathrm{Si}$ available for recycling and net benthic fluxes of $\mathrm{Si}(\mathrm{OH})_{4}$ to pelagic waters. An estimate of the contribution of benthic diffusive fluxes of $\mathrm{Si}(\mathrm{OH})_{4}$ (calculated from diffusive gradients at the sediment-water interface and integrated over the whole estuarine area) to the dissolved $\mathrm{Si}(\mathrm{OH})_{4}$ inputs to pelagic waters varied from $<3 \%$ to $>50 \%$ of the $\mathrm{Si}(\mathrm{OH})_{4}$ flux (i.e. river and benthic flux) in winter and summer, respectively. This confirms that sediments of shallow estuaries are potentially important for pelagic coastal ecosystems, in particular in summer under low river flow conditions. The contribution of benthic recycling to sustain the growth of pelagic diatoms has already been shown in different shallow coastal areas (Yamada and D'Elia, 1984; Struyf et al., 2006), and especially during limiting conditions during summer in the Bay of Brest (Del Amo et al., 1997b; Ragueneau et al., 2002a), where it prevents the development of flagellates (Laruelle et al., 2009).

From a regional and global biogeochemical point of view, our study brings new data on the Si cycle, including retention, in two small macrotidal estuaries that belong to the same estuarine type according to most of estuarine typologies (e.g. Dürr et al., 2011b). This study is in line with the approach proposed by Ragueneau et al. (2010), i.e. developing a typology of land-ocean continuums and studying $\mathrm{Si}$ retention in one type of continuum under different climatic zones, or different types of continuum under the same climatic zone, to derive the most important mechanisms driving $\mathrm{Si}$ retention. At this stage, such an effort has been undertaken in regional seas by Meybeck et al. (2007), but it needs to be pursued in other systems (e.g. fjords, deltas, mangroves, etc; Dürr et al., 2011a) as insufficient data exist for the Si cycle to do so (Ragueneau, 2004). Our study suggests that the concept of typology may have to be refined. Indeed, even if the Elorn and Aulne estuaries belong to the same macrotidal estuarine type (Dürr et al., 2011a,b), the two estuaries show different variability patterns which have implications in terms of Si retention. The higher variability in the Aulne Estuary at various scales (CV; Table 2) confirms that meanders generate heterogeneity in the benthic Si cycle, as well as transient retention, at a small local scale. Such differences have also been observed at the regional scale where $\mathrm{Si}(\mathrm{OH})_{4}$ yields can be different for similar lithology and must be regionally calibrated (Jansen et al., 2010). Thus, estuarine sub-types need to be taken into account in typologies, on the basis of new traits. From this study, meandering could be a useful descriptor, considering that more studies on Si cycle in meanders are first needed to precise the impact of transient and/or permanent $\mathrm{Si}$ retention occurring in meandering estuaries.

\section{Acknowledgements}

This work was supported by the French National Program for Coastal Environment (PNEC-EC2CO), and the salary of M. Raimonet was funded by the Ministère de l'Enseignement Supérieur et de la Recherche. We gratefully thank the R/V Côtes de la Manche crew, Agnès Youenou, Christophe Rabouille, Bruno Bombled, Julien Quéré, Emma Michaud, Anniet Laverman, Eric Viollier, and Chen 
Yan for their valuable aid with core sampling and processing, Erwan Amice and Robert Marc for their helpful assistance on board the Hésione (IUEM), and Tualenn Le Roch and Rudolph Corvaisier for their participation in $\mathrm{aSiO}_{2}$ analyses. We sincerely thank the anonymous reviewers for their very insightful and detailed comments, Anniet Laverman for her advices for the structure, illustration and language of the manuscript, and the editor Mike Elliott for constructive general comments and language edition.

\section{Appendix A. Supplementary data}

Supplementary data related to this article can be found at http:// dx.doi.org/10.1016/j.ecss.2012.12.008.

\section{References}

Aller, R.C., 1980. Quantifying solute distributions in the bioturbated zone of marine sediments by defining an average microenvironment. Geochimica et Cosmochimica Acta 44, 1955-1965.

Andrieux-Loyer, F., Philippon, X., Bally, G., Kérouel, R., Youenou, A., Le Grand, J., 2008. Phosphorus dynamics and bioavailability in sediments of the Penzé Estuary (NW France): in relation to annual P-fluxes and occurrences of Alexandrium Minutum. Biogeochemistry 88, 213-231.

Arndt, S., Regnier, P., 2007. A model for the benthic-pelagic coupling of silica in estuarine ecosystems: sensitivity analysis and system scale simulation. Biogeosciences 4, 331-352.

Bassoulet, P., 1979. Etude de la dynamique des sédiments en suspension dans l'estuaire de l'Aulne (rade de Brest). Thèse de doctorat, Université de Bretagne Occidentale, Brest, France, 136 pp.

Becquevort, S., Bouvier, T., Lancelot, C., Cauwet, G., Deliat, G., Egorov, V.N., Popovichev, V.N., 2002. The seasonal modulation of organic matter utilization by bacteria in the Danube-Black Sea mixing zone. Estuarine, Coastal and Shelf Science 54, 337-354.

Bernard, C.Y., Laruelle, G.G., Slomp, C.P., Heinze, C., 2010. Impact of changes in river fluxes of silica on the global marine silicon cycle: a model comparison. Biogeosciences 7 (2), $441-453$.

Berner, R.A., 1980. Early Diagenesis: a Theoretical Approach. Princeton University Press.

Bidle, K.D., Azam, F., 1999. Accelerated dissolution of diatom silica by marine bacterial assemblages. Nature 397, 508-512.

Blecker, S.W., McCulley, R.L., Chadwick, O.A., Kelly, E.F., 2006. Biologic cycling of silica across a grassland bioclimosequence. Global Biogeochemical Cycles 20, GB3023.

Boudreau, B.P., 1997. Diagenetic Models and their Implementation. Modelling Transport and Reactions in Aquatic Sediments. Springer-Verlag, Berlin, 414 pp.

Boudreau, B.P., Marinelli, R.L., 1994. A modelling study of discontinuous biological irrigation. Journal of Marine Research 52, 947-968.

Chatelain, M., 2010. Flux dissous à l'interface eau-sédiment sous des écoulements oscillants. Ph.D. thesis, Université Pierre et Marie Curie, Paris, 200 pp.

Cloern, J.E., 2001. Our evolving conceptual model of the coastal eutrophication problem. Marine Ecology Progress Series 210, 223-253.

Conley, D.J., 1997. Riverine contribution of biogenic silica to the oceanic silica budget. Limnology and Oceanography 42 (4), 774-776.

Conley, D.J., 2002. Terrestrial ecosystems and the global biogeochemical silica cycle. Global Biogeochemical Cycles 16 (4), 1121. http://dx.doi.org/10.1029/ 2002GB001894.

Conley, D.J., Schelske, C.L., Stoermer, E.F., 1993. Modification of the biogeochemical cycle of silica with eutrophication. Marine Ecology Progress Series 101, 179-192.

Dalrymple, R.W., Choi, K., 2007. Morphologic and facies trends through the fluvialmarine transition in tide-dominated depositional systems: a schematic framework for environmental and sequence-stratigraphic interpretation. EarthScience Reviews 81, 135-174.

Del Amo, Y., Le Pape, O., Tréguer, P., Quéguiner, B., Ménesguen, A., Aminot, A., 1997a. Impacts of high-nitrate freshwater inputs on macrotidal ecosystems. I. Seasonal evolution of nutrient limitation for the diatom-dominated phytoplankton of the Bay of Brest (France). Marine Ecology Progress Series 161, 213-224.

Del Amo, Y., Quéguiner, B., Tréguer, P., Breton, H., Lampert, L., 1997b. Marine Ecology Progress Series 161, 225-237.

DeMaster, D.J., 1981. The supply and accumulation of silica in the marine environment. Geochimica et Cosmochimica Acta 45 (10), 1715-1732.

Dixit, S., Van Cappellen, P., 2002. Surface chemistry and reactivity of biogenic silica. Geochimica et Cosmochimica Acta 66 (14), 2559-2568.

Dixit, S., Van Cappellen, P., van Bennekom, A.J., 2001. Processes controlling solubility of biogenic silica and pore water build-up of silicic acid in marine sediments. Marine Chemistry 73 (3-4), 333-352.

Dürr, H.H., Meybeck, M., Hartmann, J., Laruelle, G.G., Roubeix, V., 2011a. Global spatial distribution of natural riverine silica inputs to the coastal zone. Biogeosciences 8, 597-620.

Dürr, H.H., Laruelle, G.G., van Kempen, C., Slomp, C.P., Meybeck, M., Middelkoop, H., 2011b. Worldwide typology of nearshore coastal systems: defining the estuarine filter of river inputs to the oceans. Estuaries and Coasts 34 (3), 441-458.
Dutilleul, P., 1993. Spatial heterogeneity and the design of ecological field experiments. Ecology 74, 1646-1658.

Fraysse, F., Pokrovsky, O.S., Schott, J., Meunier, J.-D., 2009. Surface chemistry and reactivity of plant phytoliths in aqueous solutions. Chemical Geology 258, 197-206.

Gérard, F., Mayer, K.U., Hodson, M.J., Ranger, J., 2008. Modelling the biogeochemical cycle of silicon in soils: application to a temperate forest ecosystem. Geochimica et Cosmochimica Acta 72, 741-758.

Hermann, M.J., Heip, C.H.R., 1999. Biogeochemistry of the MAximum TURbidity Zone of Estuaries (MATURE): some conclusions. Journal of Marine Systems 22 (2-3), 89-104.

Howarth, R., Chan, F., Conley, D.J., Garnier, J., Doney, S.C., Marino, R., Billen, G., 2011 Coupled biogeochemical cycles: eutrophication and hypoxia in temperate estuaries and coastal marine ecosystems. Frontiers in Ecology and the Environment 9, 18-26.

Humborg, C., Ittekkot, V., Cociasu, A., Bodungen, B.V., 1997. Effect of Danube River dam on Black Sea biogeochemistry and ecosystem structure. Nature 386 (6623) 385-388.

Hunt, R.J., Krabbenhoft, D.P., Anderson, M.P., 1997. Assessing hydrogeochemical heterogeneity in natural and constructed wetlands. Biogeochemistry 39, 271-293.

Hydes, D.J., Liss, P.S., 1976. Fluorimetric method for the determination of low concentrations of dissolved aluminium in natural waters. Analyst 101, 922-931.

Jahnke, R.A., Alexander, C.R., Kostka, J.E., 2003. Advective pore water input of nutrients to the Satilla River Estuary, Georgia, USA. Estuarine, Coastal and Shelf Science 56, 641-653.

Jansen, N., Hartmann, J., Lauerwald, R., Dürr, H.H., Kempe, S., Loos, S., Middelkoop, H., 2010. Dissolved silica mobilization in the conterminous USA. Chemical Geology 270 (1-4), 90-109.

Khalil, K., Rabouille, C., Gallinari, M., Soetaert, K., DeMaster, D.J., Ragueneau, O., 2007. Constraining biogenic silica dissolution in marine sediments: a comparison between diagenetic models and experimental dissolution rates. Marine Chemistry 106 (1-2), 223-238.

Lague, D., Davy, P., Crave, A., 2000. Estimating uplift rate and erodibility from the area-slope examples from Brittany (France) and numerical modelling. Physics and Chemistry of the Earth 25 (6-7), 543-548.

Laruelle, G.G., Regnier, P., Ragueneau, O., Kemp, M., Moriceau, B., Ni Longphuirt, S., Leynaert, A., Thouzeau, G., Chauvaud, L., 2009. Benthic-pelagic coupling and the seasonal silica cycle in the Bay of Brest (France): new insights from a coupled physical-biological model. Marine Ecology Progress Series 385, 15-32.

Lettmann, K.A., Riedinger, N., Ramlau, R., Knab, N., Böttcher, M.E., Khalili, A., Wolff, J.-O., Jørgensen, B.B., 2012. Estimation of biogeochemical rates from concentration profiles: a novel inverse method. Estuarine, Coastal and Shelf Science 100, 26-37.

Leynaert, A., Ní Longphuirt, S., An, S., Lim, J.-H., Claquin, P., Grall, J., Kwon, B.O. Koh, C.H., 2011. Tidal variability in benthic silicic acid fluxes and microphytobenthos uptake in intertidal sediment. Estuarine, Coastal and Shelf Science 95 (1), 59-66.

Livingston, R., 1987. Field sampling in estuaries: the relationship of scale to variability. Estuaries and Coasts 10, 194-207.

Matisoff, G., Bricker, O.P., Holdren, G.R., Kaerk, P., 1975. Spatial and temporal variations in the interstitial waters chemistry of Chesapeake Bay sediments. In: Church, T.M. (Ed.), Marine Chemistry in the Coastal Environment, American Chemical Society Symposium Series 18. Washington, DC. pp. 343-363.

McKee, B.A., Nittrouer, C.A., DeMaster, D.J., 1983. Concepts of sediment deposition and accumulation applied to the continental shelf near the mouth of the Yangtze River. Geology 11, 631-633.

McManus, J., Hammond, D.E., Berelson, W.M., Kilgore, T.E., Demaster, D.J. Ragueneau, O.G., Collier, R.W., 1995. Early diagenesis of biogenic opal: dissolution rates, kinetics, and paleoceanographic implications. Deep Sea Research Part II: Topical Studies in Oceanography 42 (2-3), 871-903.

Meire, P., Ysebaert, T., Van Damme, S., Van den Bergh, E., Maris, T., Struyf, E., 2005 The Scheldt Estuary: a description of a changing ecosystem. Hydrobiologia 540 $1-11$.

Mermillod-Blondin, F., François-Carcaillet, F., Rosenberg, R., 2005. Biodiversity of benthic invertebrates and organic matter processing in shallow marine sediments: an experimental study. Journal of Experimental Marine Biology and Ecology 315, 187-209.

Meybeck, M., Dürr, H.H., Roussennac, S., Ludwig, W., 2007. Regional seas and their interception of riverine fluxes to oceans. Marine Chemistry 106, 301-325.

Meysman, P.J.R., Middelburg, J.J., Heip, C.H.R., 2006. Bioturbation: a fresh look at Darwin's last idea. Trends in Ecology \& Evolution 21 (12), 688-695.

Michalopoulos, P., Aller, R.C., 2004. Early diagenesis of biogenic silica in the Amazon delta: alteration, authigenic clay formation, and storage. Geochimica et Cosmochimica Acta 68 (5), 1061-1085.

Montgoméry, J.R., Zimmermann, C.F., Price, M.T., 1979. The collection, analysis and variation of nutrients in estuarine pore water. Estuarine and Coastal Marine Science 9 (2), 203-214.

Moosdorf, N., Hartmann, J., Lauerwald, R., 2011. Changes in dissolved silica mobilization into river systems draining North America until the period 2081-2100. Journal of Geochemical Exploration 110 (1), 31-39.

Moriceau, B., Garvey, M., Ragueneau, O., Passow, U., 2007. Evidence for reduced biogenic silica dissolution rates in diatom aggregates. Marine Ecology Progress Series 333, 129-142.

Moriceau, B., Goutx, M., Guigue, C., Lee, C., Armstrong, R., Duflos, M., Tamburini, C., Charrière, B., Ragueneau, O., 2009. Si-C interactions during degradation of the 
diatom Skeletonema marinoi. Deep Sea Research Part II: Topical Studies in Oceanography 56 (18), 1381-1395.

Mouret, A., 2009. Biogéochimie benthique: processus et divergences entre les sédiments littoraux et ceux des marges continentales. In: Biogéochimie marine. Université de Bordeaux 1, Bordeaux, p. 157.

Ni Longphuirt, S., Ragueneau, O., Chauvaud, L., Martin, S., Jean, F., Thouzeau, G., Leynaert, A., 2009. Diurnal heterogeneity in silicic acid fluxes in shallow coasta sites: causes and implications. Estuarine, Coastal and Shelf Science 82, 495-502.

Nichols, F.H., Cloern, J.E., Luoma, S.N., Peterson, D.H., 1986. The modification of an estuary. Science 231, 567-573.

Odum, W.E., 1984. Dual-gradient concept of detritus transport and processing in estuaries. Bulletin of Marine Science 35 (3), 510-521 (12).

Officer, C.B., Ryther, J.H., 1980. The possible importance of silicon in marine eutrophication. Marine Ecology Progress Series 3, 83-91.

Poff, N.L., 2009. Managing for variability to sustain freshwater ecosystems. Journal of Water Resources Planning and Management 135 (1), 1-4.

Querné, J., 2011. Invasion de Spartina alterniflora dans les marais de la rade de Brest. Comportement invasif et impact sur le cycle biogéochimique du silicium. Ph.D. thesis, Université de Bretagne Occidentale, Brest, France, 217 pp.

Ragueneau, O., 2004. Si-WEBS, a European Network for the Study of Si Fluxes on Continental Margins. LOICZ Newsletter 31, 1-4.

Ragueneau, O., Tréguer, P., Leynaert, A., Anderson, R.F., Brzezinski, M.A. DeMaster, D.J., Dugdale, R.C., Dymond, J., Fischer, G., François, R., Heinze, C., Maier-Reimer, E., Martin-Jézéquel, V., Nelson, D.M., Quéguiner, B., 2000. A review of the Si cycle in the modern ocean: recent progress and missing gaps in the application of biogenic opal as a paleoproductivity proxy. Global and Planetary Change 26 (4), 317-365.

Ragueneau, O., Chauvaud, L., Leynaert, A., Thouzeau, G., Paulet, Y.-M., Bonnet, S., Lorrain, A., Grall, J., Corvaisier, R., Hir, M.L., Jean, F., Clavier, J., 2002a. Direct evidence of a biologically active coastal silicate pump: ecological implications. Limnology and Oceanography 47 (6), 1849-1854.

Ragueneau, O., Lancelot, C., Egorov, V., Vervlimmeren, J., Cociasu, A., Déliat, G., Krastev, A., Daoud, N., Rousseau, V., Popovitchev, V., Brion, N., Popa, L., Cauwet, G. 2002b. Biogeochemical transformations of inorganic nutrients in the mixing zone between the Danube river and the North-western Black Sea. Estuarine, Coastal and Shelf Science 54, 321-336.

Ragueneau, O., Savoye, N., Del Amo, Y., Cotton, J., Tardiveau, B., Leynaert, A., 2005. A new method for the measurement of biogenic silica in suspended matter of coastal waters: using Si:Al ratios to correct for the mineral interference. Continental Shelf Research 25 (5-6), 697-710.

Ragueneau, O., Conley, D.J., DeMaster, D.J., Dürr, H.H., Dittert, N., 2010. Biogeochemical transformations of silicon along the land-ocean continuum and implications for the global carbon cycle. In: Liu, K.K., et al. (Eds.), Carbon and Nutrient Fluxes in Continental Margins. Global Change. The IGBP Series. Springer Berlin, Heidelberg, Berlin, pp. 515-527.

Raimonet, M., 2011. Benthic Silica Cycle in Estuaries: Monitoring and Modelling at Different Spatio-temporal Scales. Ph.D. thesis, Université de Bretagne Occidentale, Brest, 179 pp.

Rebreanu, L., 2009. Study of the Si Biogeochemical Cycle in the Sediments of the Scheldt Continuum (Belgium/The Netherlands). Ph.D. thesis, Université libre de Bruxelles, Brussels, 220 pp.

Regnier, P., Mouchet, A., Wollast, R., Ronday, F., 1998. A discussion of methods for estimating residual fluxes in strong tidal estuaries. Continental Shelf Research 18 (13), 1543-1571.

Rickert, D., Schlüter, M., Wallmann, K., 2002. Dissolution kinetics of biogenic silica from the water column to the sediments. Geochimica et Cosmochimica Acta 66, 439-455.

Roubeix, V., Becquevort, S., Lancelot, C., 2008. Influence of bacteria and salinity on diatom biogenic silica dissolution in estuarine systems. Biogeochemistry 88 , $47-62$.

Roy, S., Gaillardet, J., Allègre, C.J., 1999. Geochemistry of dissolved and suspended loads of the Seine River, France: anthropogenic impact, carbonate and silicate weathering. Geochimica et Cosmochimica Acta 63, 1277-1292.
Sakamaki, T., Nishimura, O., Sudo, R., 2006. Tidal time-scale variation in nutrient flux across the sediment-water interface of an estuarine tidal flat. Estuarine, Coastal and Shelf Science 67, 653-663.

Shum, K.T., Sundby, B., 1996. Organic matter processing in continental shelf sediments - the subtidal pump revisited. Marine Chemistry 53, 81-87.

Smetacek, V.S., 1985. Role of sinking in diatom life-history cycles: ecological, evolutionary and geological significance. Marine Biology 84 (3), 239-251.

Smis, A., Van Damme, S., Struyf, E., Clymans, W., Van Wesemael, B., Frot, E., Vandevenne, F., Van Hoestenberghe, T., Govers, G., Meire, P., 2010. A trade-off between dissolved and amorphous silica transport during peak flow events (Scheldt river basin, Belgium): impacts of precipitation intensity on terrestrial Si dynamics in strongly cultivated catchments. Biogeochemistry 106, 475-487.

Stieglitz, T., Ridd, P., Müller, P., 2000. Passive irrigation and functional morphology of crustacean burrows in a tropical mangrove swamp. Hydrobiologia 421, 69-76.

Struyf, E., Conley, D.J., 2009. Silica: an essential nutrient in wetland biogeochemistry. Frontiers in Ecology and the Environment 7 (2), 88-94.

Struyf, E., Dausse, A., Van Damme, S., Bal, K., Gribsholt, B., Boschker, H.T.S. Middelburg, J.J., Meire, P., 2006. Tidal marshes and biogenic silica recycling at the land-sea interface. Limnology and Oceanography 51 (2), 838-846.

Swaney, D.P., Giordani, G., 2007. Proceedings of the LOICZ Workshop on Biogeochemical Budget Methodology and Applications, Providence, Rhode Island, November 9-10, 2007. LOICZ Research \& Studies No. 37. Helmholtz-Zentrum Geesthacht, 195 pp.

Swaney, D.P., Humborg, C., Emeis, K., Kannen, A., Silvert, W., Tett, P., Pastres, R. Solidoro, C., Yamamuro, M., Hénocque, Y., Nicholls, R., 2012. Five critical questions of scale for the coastal zone. Estuarine, Coastal and Shelf Science 96, $9-21$.

Tréguer, P.J., Le Corre, P., 1975. Manuel d'analyse des sels nutritifs dans l'eau de mer: utilisation de l'auto-analyseur Technicon II. Université de Bretagne Occidentale, Brest, France.

Tréguer, P.J., Nelson, D.M., Van Bennekom, A.J., DeMaster, D.J., Leynaert, A., Quéguiner, B., 1995. The silica balance in the world ocean: a reestimate. Science 268 (5209), 375-379.

Tréguer, P.J., De La Rocha, C.L., 2013. The world ocean silica cycle. Annual Review of Marine Science 5, 477-501.

Van Cappellen, P., Qiu, L., 1997a. Biogenic silica dissolution in sediments of the Southern Ocean. I. Solubility. Deep Sea Research Part II: Topical Studies in Oceanography 44 (5), 1109-1128.

Van Cappellen, P., Qiu, L., 1997b. Biogenic silica dissolution in sediments of the Southern Ocean. II. Kinetics. Deep Sea Research Part II: Topical Studies in Oceanography 44 (5), 1129-1149.

Vanderborght, J-P. Wollast, R, Billen, G, 1977. Kinetic models of diagenesis in disturbed sediments. Part 1 . Mass transfer properties and silica diagenesis. Limnology and Oceanography 22 (5), 787-793.

Vieillard, A.M., Fulweiler, R.W., Hughes, Z.J., Carey, J.C., 2011. The ebb and flood of Silica: quantifying dissolved and biogenic silica fluxes from a temperate salt marsh. Estuarine, Coastal and Shelf Science 95 (4), 415-423.

Waldbusser, G.G., Marinelli, R.L., Whitlatch, R.B., Visscher, P.T., 2004. The effects of infaunal biodiversity on biogeochemistry of coastal marine sediments. Limnology and Oceanography 49 (5), 1482-1492.

Webster, I.T., Smith, S.V., Parslow, J.S., 2000. Implications of spatial and temporal variation for biogeochemical budgets of estuaries. Estuaries and Coasts 23 (3), 341-350.

Wilson, A.M., Morris, J.T., 2012. The influence of tidal forcing on groundwater flow and nutrient exchange in a salt marsh-dominated estuary. Biogeochemistry 108 $(1-3), 27-38$

Wolfe, D., Champ, M., Flemer, D., Mearns, A., 1987. Long-term biological data sets: their role in research, monitoring, and management of estuarine and coastal marine systems. Estuaries and Coasts 10, 181-193.

Yamada, S.S., D'Elia, C.F., 1984. Silicic acid regeneration from estuarine sediment cores. Marine Ecology Progress Series 18, 113-118. 